\title{
Relações Intertextuais entre Canções de Nepomuceno sobre Poemas Parnasianos e Simbolistas e a Mélodie Francesa: Coração triste e Canção da ausência
}

\author{
Intertextual Relations between Nepomuceno's songs on Parnassian and \\ Symbolist poems and the French Mélodie: Coração triste and Canção da \\ ausência
}

\author{
Eliana Asano Ramos \\ Maria Yuka de Almeida Prado \\ Universidade de São Paulo
}

\begin{abstract}
Resumo: Partindo da hipótese que a passagem de Nepomuceno para estudos na França causou grande impacto em Nepomuceno, levando-o a adotar a Mélodie como modelo em suas canções, o objetivo deste artigo é analisar obras paradigmáticas buscando demonstrar as relações e compreender o processo de assimilação. Objetivamos mostrar possíveis referências de Alberto Nepomuceno (1964-1920) a Gabriel Fauré (1845-1924) em duas de suas canções, Coração triste e Canção da ausência. O processo analítico, de natureza comparativa e interdisciplinar, tem como referencial teórico Stein e Spillman (1996) na análise de relações texto-música, bem como Klein (2005), Reynolds (2003) e Straus (1990) na análise das estratégias intertextuais, não se furtando à identificação de aspectos que possam contribuir à caracterização do estilo composicional de Nepomuceno, trazendo à luz a consciência de relação entre Nepomuceno e as correntes modernistas francesas.
\end{abstract}

Palavras-chave: Alberto Nepomuceno; Canção de câmara brasileira; Intertextualidade em música

Abstract: Departing from the hypothesis that France caused a significant impact on Nepomuceno, enabling him to adopt the French Mélodie as a model for his songs, the objective of this article is to analyze paradigmatic works in order to demonstrate the relations and comprehend how the process of assimilation occurred. The analytical process, of comparative and interdisciplinary nature, has basis on Stein and Spillman (1996) for the textmusic relations, besides as Klein (2005), Reynolds (2003), and Straus (1990) for the intertextual strategies analysis, not shying away from identifying aspects that characterize Nepomuceno's compositional style, revealing the link between Nepomuceno and French modernistic currents.

Keywords: Alberto Nepomuceno; Brazilian chamber song; Intertextuality in music 
MUSICA THEORICA Revista da Associação Brasileira de Teoria e Análise Musical 2020, v. 5, n. 1, p. 242-277 - Journal of the Brazilian Society for Music

Sempre que lemos um texto que nos remete a outro(s) texto(s) estamos diante de um caso de intertextualidade.

Nenhum texto veicula informações cem por cento inéditas, assim como nenhum texto é cem por cento novo [...]. Qualquer texto lembra, retoma ou evoca, implícita ou explicitamente, outro texto ou parte de algum texto. A essa propriedade, que é também uma espécie de conhecimento compartilhado-só que numa dimensão social e histórica-chamamos intertextualidade (Azeredo 2007, p. 25-26).

O termo intertextualidade foi empregado pela primeira vez nos estudos literários de Julia Kristeva (1941-), desenvolvidos a partir da noção de dialogismo-diálogo de um texto, interno e externo, com diferentes vozes e outros textos-verificado por Mikhail Bakhtin (1985-1975) em romances do século XIX.

O texto é, portanto, uma ... permutação de textos, uma intertextualidade: em um espaço de um dado texto, vários enunciados, tirados de outros textos, interagem e neutralizam uns aos aos outros ${ }^{1}$ (KRISTEVA 1980, p. 36 apud KLEIN 2005, p. 2, tradução nossa).

A prática intertextual, no entanto, "não é uma novidade dos tempos pósmodernos" (Coelho de Souza 2009, p. 53). Nas artes em geral, a imitação era considerada um procedimento importante de prática e até mesmo de criação (Carvalhal 2007, p. 52). Aristóteles já falava sobre a influência de Homero nos poetas de seu tempo (Coelho de Souza 2009, p. 53). E na música, o empréstimo de melodias do cantochão para a composição de uma nova peça era uma prática comum na Idade Média e na Renascença (Grout e Palisca 1997, p. 37; Burkholder 1994, p. 851).

Podemos afirmar, portanto, que a intertextualidade é um fenômeno arcaico, onipresente, e que permeia, de modo complexo, as artes de todos os tempos em nossa cultura ocidental (Coelho de Souza 2009, p. 54).

O problema, no entanto, é que, antes de Kristeva, não havia ainda uma teoria intertextual sólida. A partir de então, os estudos de comparação passam a incorporar uma reflexão crítica a partir do estabelecimento de classificações

\footnotetext{
1 "The text is therefore a ... permutation of texts, an intertextuality: in the space of a given text, several utterances, taken from other texts, intersect and neutralize one another" (Kristeva 1980, p. 36 apud Klein 2005, p. 2).
} 
Relações Intertextuais entre Canções de Nepomuceno sobre Poemas Parnasianos e Simbolistas e a Mélodie Francesa: Coração triste e Canção da ausência

tipológicas, procurando dar explicação para as relações através de uma teoria elaborada, dotada de uma terminologia específica. O foco da interpretação analítica passa do criador para o receptor (Beard e Gloag 2016, p. 142) e há uma busca pela interpretação dos motivos que geraram as relações e por uma caracterização dos procedimentos efetuados (Carvalhal 2007, p. 52-53).

Trata-se de explorar criticamente os dois textos, ver como eles se misturam e, a partir daí, como, repetindo-o, o segundo texto "inventa" o primeiro. Dessa forma ele o redescobre, dando-lhe outros significados já não possíveis nele mesmo (Carvalhal 2007, p. 58).

Mas a intenção aqui não é rastreio. É de leitura intertextual. Vemos que um poema lê outro e queremos saber como e por quê (Carvalhal 2007, p. 53).

O termo, no entanto, não ficou restrito às discussões das artes literárias e rapidamente se alastrou para outros campos de pesquisa. É comum encontrá-lo em discussões sobre cinema, pintura, música, arquitetura, fotografia, propaganda e marketing, entre outras manifestações artísticas (Allen 2011, p. 169).

[...] a intertextualidade ajuda a entender que o significado não está constituído apenas pelo texto interpretado, mas também pelos outros textos que o(s) intérprete(s) utilizam para dar sentido ou interpretar o(s) texto(s) em questão (Martínez Pèrez 2012, p. 134).

Nos estudos musicais, o termo passou a ser empregado a partir da década de 1980, sobretudo em estudos sobre a influência, frequentemente empregado para descrever relações entre diferentes compositores, obras ou períodos. Influência é um tipo específico de intertextualidade que implica intenção de empréstimo ou alusão de um autor a outro e localização histórica dentro de uma linha de tempo unidirecional (Klein 2005, p. 11-12). As discussões sobre a intertextualidade em música tiveram como principal ponto de partida os estudos literários do americano Harold Bloom (1930-2019), cuja teoria está centrada no processo de releitura que os poetas fazem de seus precursores. Bloom (1973) apresenta uma reflexão sobre a literatura comparada, esboçando uma teoria poética que vai de encontro a uma prática crítica sobre a intertextualidade (Carvalhal 2007, p. 60). Em música, o exemplo mais citado é o terceiro movimento da Sinfonia (1968-1969) de Luciano Berio (1925-2003), escrita para oito vozes amplificadas e orquestra. O movimento é baseado no terceiro movimento da Sinfonia no 2 (1894) de Gustav Mahler (1860-1911) e inclui citações e alusões a 
vários outros compositores, como J. S. Bach (1685-1750), L. Van Beethoven (17701827), Hector Berlioz (1803-1869), C. Debussy (1862-1918), R. Strauss (18641949), A. Schoenberg (1874-1951), M. Ravel (1875-1937), A. Webern (1883-1945), I. Stravinsky (1882-1971), A. Berg (1885-1935), P. Hindemith (1895-1963), P. Boulez (1925-2016), entre outros.

Três importantes teóricos musicais merecem destaque no que diz respeito às discussões iniciais sobre a intertextualidade em música: Korsyn (1991), Straus (1990, 1991) e Klein (2005). Kevin Korsyn, em “Towards a New Poetics of Musical Influence" (1991), propõe uma teoria da intertextualidade em música por meio de um modelo de mapeamento da influência, estabelecendo relações entre os tropos retóricos de Bloom (1973) e correlatos musicais. Segundo o autor, a análise textual não deve envolver apenas o acúmulo de informações ou similaridades entre as peças, mas é importante que haja modelos que ajudem a explicar tanto as similaridades quanto as diferenças entre elas. Segundo Beard e Gloag (2016, p. 139), é justamente essa procura por modelos de explicação e interpretação que leva Korsyn (1991) em direção aos trabalhos de Bloom (1973). Joseph N. Straus, em Remaking the Past (1990) e The "Anxiety of Influence" in Twentieth-Century Music (1991), investiga como os compositores do início do século XX lidaram com a herança musical tonal, como eles incorporaram e repensaram a linguagem de seus antecessores. Straus interpreta o Modernismo musical não como uma negação completa da prática musical tradicional, mas como uma reinterpretação original e radical dela. $\mathrm{O}$ autor usa a teoria dos conjuntos em suas análises musicais para demonstrar relações mais profundas. Michael L. Klein, em Intertextuality in Western Art Music (2005), também procura identificar as relações entre a música tonal e a música dos séculos XX e XXI. Segundo o autor, não se trata de uma teoria da intertextualidade, mas sugestões de abordagem, procurando também mostrar possíveis relações.

Em música, outro termo que atualmente vem sendo empregado com frequência em estudos sobre a intertextualidade em música é empréstimo musical, como nos trabalhos do americano Burkholder (1994, p. 861-862), que usa o termo para representar os usos de música pré-existente, incluindo casos de citação direta a alusões sem referência explícita. Outra importante contribuição do pesquisador é um extenso banco de pesquisas sobre o empréstimo musical disponibilizado na internet, pois considera que o compartilhamento de informações entre pesquisadores é uma ferramenta essencial no estudo da 
Relações Intertextuais entre Canções de Nepomuceno sobre Poemas Parnasianos e Simbolistas e a Mélodie Francesa: Coração triste e Canção da ausência

intertextualidade. No Grove Music Online, é de Burkholder a definição de empréstimo musical: “O uso em uma peça musical de um ou mais elementos tirados de uma outra peça específica", ${ }^{2}$ assim como a definição de intertextualidade: “Um termo, empregado pela crítica literária Julia Kristeva, que abrange toda a gama de relações entre textos, de empréstimo direto, reelaboração ou citação a estilos, convenções ou linguagem compartilhadas". ${ }^{3}$ No artigo "The Uses of Existing Music: Musical Borrowing as a Field" (1994), o musicólogo defende o empréstimo musical como um campo de estudo e descreve quatorze tipologias de empréstimo musical encontradas em suas análises sobre a música de Ives, as quais podem ser, segundo o autor, comumente encontradas em obras de outros compositores. Ao final do artigo, o autor oferece um questionário com o objetivo de ajudar o analista na identificação dos diferentes tipos de empréstimo musical (Burkholder 1994, p. 867-870).

Outro trabalho tão importante e atual é Motives for Allusion: Context and Content in Nineteenth-Century Music (2003), de Christopher A. Reynolds. Além de oferecer um estudo de tipologias pertinentes para o estudo da alusão na música, o autor também discute intenção e significado, além da probabilidade de reconhecimento da audiência. $\mathrm{O}$ empréstimo de um motivo pré-existente era uma prática comum na música do século XIX e tinha uma conotação simbólica, acreditava-se que o empréstimo de um motivo também implicava em empréstimo de significado (Klein 2006, p. 111).

No estudo da música brasileira, o conceito de intertextualidade também é empregado sob diferentes enfoques. Para Lima e Pitombeira (2011), por exemplo, a intertextualidade em música pode ocorrer em dois níveis: estilístico (sem enfocar uma obra específica) e estratégico (de modo proposital, enfocando uma ou mais obras; de maneira literal, podendo incluir algumas pequenas modificações; ou abstrata, deixando apenas resíduos do texto precursor). Barbosa e Barrenechea $(2003,2005)$ analisam a relação de influência da música do

\footnotetext{
2 "The use in a piece of music of one or more elements taken from another specific piece". Disponível em <http://www.oxfordmusiconline.com/subscriber/article/grove/music/A2240263>. Acesso em: 27 jan. 2017.

3 "A term, coined by the literacy critic Julia Kristeva, that encompasses the entire range of relationships between texts, from direct borrowing, reworking or quotation to shared styles, conventions or language". Disponível em <http://www.oxfordmusiconline.com/ subscriber/article/grove/music/52853>. Acesso em: 27 jan. 2017.
} 
MUSICA THEORICA Revista da Associação Brasileira de Teoria e Análise Musical 2020,

v. 5, n. 1, p. 242-277 - Journal of the Brazilian Society for Music

compositor polonês Frederic Chopin (1810-1849) sobre a música do compositor brasileiro Francisco Mignone (1897-1896), incluindo uma descrição de tipologias e a apresentação de um modelo de análise "para assim descrever a influência do compositor polonês nestas obras" (Barbosa e Barrenechea 2005, p. 41). A intertextualidade enquanto uma ferramenta composicional pós-moderna na música do século XXI é discutida por Escudeiro (2015, p. 139), segundo o qual a “possibilidade de apropriação de materiais e técnicas diversos é extremamente pertinente a estética intertextual". Para Coelho de Souza (2009), a intertextualidade ajuda a distinguir o Modernismo do Pós-Modernismo em música. Segundo o autor, a estética do Modernismo na primeira metade do século XX foi marcada pela originalidade, ou seja, pela ruptura com as tradições em favor de uma nova linguagem. Já para o Pós-Modernismo, a criação de algo novo é utópica, "já que não é possível construir uma identidade a partir do nada" (Coelho de Souza 2009, p. 54). Assim, os compositores de obras pós-modernas passaram a retomar elementos pré-existentes, abandonados e reconhecíveis, como referência para a criação de novas obras.

Por isso, muitas obras musicais da metade do século $X X$ não se envergonharam de exibir na fachada, citações e referências a outras obras. Ao contrário, proclamaram que dependiam dessas referências para se constituir [...]. servem-se de códigos estabelecidos, utilizados, porém de uma maneira dúbia em relação à convenção original (Coelho de Souza 2009, p. 54).

A noção de originalidade, vista como sinônimo de "geração espontânea", criação desligada de qualquer vínculo com obras anteriores, cai por terra (Carvalhal 2007, p. 63).

A prática de imitação dos grandes mestres foi adotada como procedimento de aperfeiçoamento técnico por Alberto Nepomuceno (1864-1920), o que o teria motivado a ir à Europa para estudos musicais entre os anos de 1888 e 1895, período em que esteve na Itália, Noruega, Alemanha e França. Em Roma, estudou harmonia com Eugenio Terziani (1824-1889) e Cesare de Sanctis (18301915) no Liceo Musicale Santa Cecilia (Vermes 1996, p. 30), deixando desse período de estudos quatro canções em italiano da estada na Itália. Em 1890, partiu para Berlim, onde estudou composição com Heinrich von Herzogenberg (18431900) na Meisterschule für Konposition, transferindo-se em 1892 para o Stern'sches Koservatorium, estudando composição e órgão com Arno Kleffel (1840-1913) e piano com Heinrich Ehrlich (1822-1899), tendo deixado sete 
Relações Intertextuais entre Canções de Nepomuceno sobre Poemas Parnasianos e Simbolistas e a Mélodie Francesa: Coração triste e Canção da ausência

canções em alemão, algumas de influência "brahmsiana" e outras de influência wagneriana (Pignatari 2013, p. 50), e uma em norueguês, possivelmente resultado de seu contato com Edvarg Grieg (1843-1907).

Após o tradicional e conservador ambiente alemão, Nepomuceno encontrou o moderno e ousado ambiente francês. A passagem de Nepomuceno por Paris durou um ano e aconteceu antes de seu retorno ao Brasil, período em que o compositor estudou órgão com Alexandre Guilmant (1837-1911), o qual se juntaria logo depois a Charles Bordes (1863-1909) e Vincent d'Indy (1851-1931) para fundar a Schola Cantorum, instituição privada de ensino que rivalizaria com o Conservatório de Paris, cuja principal ênfase estava no ensino da ópera, influenciada pelo wagnerianismo alemão. De sua estadia francesa, resultaram seis canções em francês, quatro com poemas de Henri Piazza (1861-1929) e duas com poemas de Maurice Maeterlinck (1862-1949), cujas ousadias harmônicas revelam o alinhamento do compositor com o que acontecia de mais moderno na música da Europa em fins do século XIX (Pignatari 2013, p. 67). Em 1894, Nepomuceno assistiu à estreia do Prélude à l'après-midi d'un Faune, de Claude Debussy, considerado por vários historiadores como o marco inicial da música moderna.

A prática de imitação dos grandes mestres pode ter sido influência direta da relação do compositor com os irmãos Henrique Bernardelli (1858-1936) e Rodolfo Bernardelli (1852-1931), artistas plásticos renomados, ambos professores da Escola Nacional de Belas Artes do Rio de Janeiro (Rodolfo também foi diretor da mesma instituição por 25 anos), com os quais o compositor foi morar assim que chegou no Rio de Janeiro. Os irmãos foram responsáveis também pelo suporte na primeira viagem de estudos do compositor à Europa, quando o governo lhe negou uma bolsa de estudos por seus ideais políticos. Ao contrário do que acontecia em música, as artes plásticas consideravam (e ainda consideram) a imitação dos grandes mestres um procedimento importante para o aperfeiçoamento técnico, "a melhor forma de se estudar e aprender arte" (Fucci 2018, p. 45). Pesquisas recentes mostram que Nepomuceno foi, sobretudo, um compositor cosmopolita, que dialogou com obras e compositores referenciais e assimilou traços estilísticos avançados para o seu tempo, contribuindo para a renovação do ambiente musical brasileiro (Pignatari 2009, p. 91; Goldberg 2007, p. 192; Coelho de Souza 2006, p. 80). 
Nepomuceno viveu em um momento de grandes transformações políticas, sociais e culturais. No Brasil, a mudança de monarquia para república, a abolição da escravatura, a instituição do trabalho assalariado, a modernização das lavouras e fazendas de café, o desenvolvimento industrial, a modernização das cidades e o desenvolvimento cultural foram apenas algumas das grandes transformações em fins do século XIX e início do século XX. Havia uma grande euforia da burguesia, formada por comerciantes, fazendeiros, financistas e empresários do ramo agroexportador, que ascendeu ao poder logo após a deposição do então imperador D. Pedro II e a Proclamação da República. Era uma elite "que dispunha de tempo ocioso e rendimento farto para usufruir as benesses materiais, intelectuais e artísticas proporcionadas pelo desenvolvimento industrial de um capitalismo em seus primórdios" (Camargos 2001, p. 21). Havia um grande esforço pela modernização do país e pela civilização da sociedade e a principal referência era Paris, cidade modelo de civilização, elegância, modernidade e progresso. Vestígios da sociedade imperial e da colonização portuguesa foram substituídos por uma fisionomia afrancesada. O Brasil passou a importar os modismos da França, incluindo mobiliários e objetos de arte, vestimentas, produtos de beleza, escolas filosóficas, livros e notícias (sobre a França). Imitava-se a França em tudo. O plano de remodelação da capital federal de Francisco Pereira Passos (1836-1913), então prefeito do Rio de Janeiro, foi inspirado na remodelação empreendida pelo barão GeorgesEugène Haussmann (1809-1891) em Paris entre os anos de 1853 e 1870. Professores particulares eram contratados para ensinar não apenas o idioma francês, mas também os costumes daquele país. Jovens eram enviados à França para estudarem em instituições de renome e tradição e famílias inteiras costumavam passar longos períodos na França, aprimorando a educação por meio de aulas particulares e visitas a museus e bibliotecas (Camargos 2001, p. 30). Nas artes, havia uma busca por uma ruptura com o passado e uma redescoberta do Brasil, embora a técnica dos movimentos anteriores não tivesse sido completamente descartada (Broca 2004, p. 313; Camargos 2001, p. 22).

De volta ao Brasil, Nepomuceno atuou como professor e diretor do Instituto Nacional de Música no Rio de Janeiro e esteve à frente de algumas outras instituições musicais, trabalhando intensamente pela divulgação da música moderna. A busca pela modernização do cenário musical brasileiro atendia justamente ao ideal republicano positivista e progressista do compositor, 
Relações Intertextuais entre Canções de Nepomuceno sobre Poemas Parnasianos e Simbolistas e a Mélodie Francesa: Coração triste e Canção da ausência

que "defendia o progresso e a educação do povo através da disseminação da cultura da elite burguesa" (Coelho de Souza 2012, p. 79), o que não implicava, no entanto, "na exclusão da cultura universal e sua substituição por uma cultura regional, pelo contrário, considerava que cabia aos homens cultos ilustrar o povo através da educação, ao mesmo tempo em que se reforçaria a identidade nacional pela incorporação de elementos da cultura popular" (Coelho de Souza 2008, p. 18). A obra de Nepomuceno, portanto, não seria resultado da ruptura com o passado, mas de influências e assimilações combinadas à personalidade sui generis do compositor.

Apesar de sua aproximação com a música moderna de sua época, a historiografia musical brasileira, dominante ao longo de todo o século $X X$ e engajada no projeto de formação de uma identidade nacional, limitou colocar o compositor como precursor do nacionalismo brasileiro, considerando os elementos característicos folclóricos em sua música, e fundador de um gênero importante para o Modernismo, a canção de câmera erudita brasileira em português, o que acabou ofuscando outras valiosas contribuições do compositor, especialmente para a formação de uma linguagem modernista brasileira. (Coelho de Souza 2010, p. 70). Houve uma excessiva valorização das obras de cunho nacionalista, enquanto que as obras de caráter genérico foram simplesmente ignoradas, acusadas muitas vezes de epigonismo, pois não atendiam ao projeto de busca por uma identidade nacionalista ao qual se apegavam os críticos modernistas (Vidal 2011, p. 130). De acordo com estudos recentes, dentre as influências encontradas na música de Nepomuceno, a mais aparente é a alemã, especialmente de Richard Wagner (1813-1883) e Johannes Brahms (1833-1897), ambos descendentes de uma tradição alemã mais conservadora e enraizada, enquanto a outra, menos aparente, porém mais moderna e ousada, é a francesa (Coelho de Souza 2010, p. 37-38).

Dentro da vasta e variada obra de Nepomuceno, abrangendo de peças para órgão e piano a grandes peças sinfônicas e óperas, são as canções que tradicionalmente recebem mais atenção, especialmente as escritas em português, muito provavelmente devido ao destaque dado pela historiografia modernista brasileira. No álbum de canções de Nepomuceno editado por Pignatari (2013), são contabilizadas cinquenta e nove composições, datadas de 1887 a 1920. Antes da sua viagem de estudos à Europa, Nepomuceno escreveu apenas uma canção em português, Ave Maria, já antecipando o modalismo predominante em obras 
posteriores (Pignatari 2009, p. 35). Na Europa, como dito anteriormente, escreveu canções em italiano, norueguês, alemão e francês. Depois que voltou ao Brasil, embora a maior parte das suas canções esteja em português, o compositor continuou a escrever em italiano, francês e alemão.

Para Coelho de Souza (2010, p. 43), no entanto, a principal contribuição de Nepomuceno para a canção de câmara brasileira foi a assimilação e a transposição dos modelos do Lied alemão e da Mélodie francesa na escrita das canções. Assim como o Lied alemão, a Mélodie francesa também nasce influenciada pelo impacto da nova poesia romântica (Noske 1970, p. 1). A parte do piano, até então um simples suporte da linha vocal, adquire uma maior importância, passando a adicionar uma maior profundidade emocional aos poemas. $\mathrm{O}$ balanço entre a música e o poema passa a ser tão importante quanto o equilíbrio entre a linha vocal e a parte do piano (Johnson e Stokes 2002, p. xiii). O desafio de juntar texto e música foi a principal preocupação dos compositores do Lied e da Mélodie, e essa preocupação é perceptível nas canções de Nepomuceno.

Descendente da tradição dos troubadours e dos romances, o termo Mélodie passou a ser usado para designar a nova canção francesa escrita nas primeiras décadas do século XIX, influenciadas, principalmente, pelas primeiras traduções e adaptações dos Lieder de Schubert para o francês (Noske 1970, p. 23). Embora a língua francesa colocasse algumas dificuldades aos compositores franceses, sobretudo com relação ao ritmo, logo os compositores passaram a perceber a versatilidade e a musicalidade inerentes ao idioma, as quais viriam a ser fundamentais para caracterizar o idioma impressionista francês (Noske 1970, p. 26). Com o tempo, a Mélodie foi desenvolvendo as suas próprias características, como formas estruturais diversas diante das novas possibilidades poéticas, em lugar das tradicionais estróficas, linha vocal mais livre, com maior valorização do enunciado poético, maior importância na parte do piano, em alguns momentos até sugerindo liderança (de papel secundário passa a contribuir para a expressividade), e valorização de versos de alto valor literário, já escrevendo sobre texto em francês, com seus versos mais livres e fluidos (Noske 1970, p. 35-38). Vários compositores contribuíram para o desenvolvimento da Mélodie, inclusive compositores não franceses: Hector Berlioz, Giacomo Meyerbeer (1791-1864), Franz Liszt (1811-1866), Henri Duparc (1848-1933), Charles Gounod (1818-1893), Georges Bizet (1838-1875), Massenet 
Relações Intertextuais entre Canções de Nepomuceno sobre Poemas Parnasianos e Simbolistas e a Mélodie Francesa: Coração triste e Canção da ausência

(1842-1912), Camille Saint-Saëns (1835-1921), Édouard Lalo (1823-1892), Cesar Franck (1822-1890), Gabriel Fauré (1845-1924), Ernest Chausson (1855-1899), Maurice Ravel, Claude Debussy, entre outros. A Mélodie levou a música francesa ao apogeu (Johnson e Stokes 2002, p. xiii).

Nepomuceno recorreu a uma gama ampla de poetas, brasileiros e estrangeiros, a maior parte praticamente desconhecida do público, um forte indício de que o foco do compositor estava nas potencialidades do poema e não na fama do poeta. Segundo Coelho de Souza (2012, p. 224), as poesias escolhidas por Nepomuceno "trazem sempre o caráter genérico do lirismo romântico, parnasiano ou simbolista", o que pode indicar um traço importante de influência da Mélodie francesa, já que o Parnasianismo e o Simbolismo foram correntes que nasceram na poesia francesa e foram adotadas pelos compositores franceses em suas canções, incluindo Debussy, em quem Nepomuceno parece ter buscado inspiração. No ano em que esteve em Paris (como dito anteriormente), Nepomuceno assistiu a estreia do Prélude à l'après-midi d'un Faune, inspirado em texto homônimo do autor parnasiano Stéphane Mallarmé (1842-1898), considerado por vários historiadores o marco inicial da música moderna. Em 1910, Nepomuceno visitou Debussy pessoalmente na França e recebeu uma cópia autografada da ópera Pelleas et Mélisande, baseada em peça homônima do autor simbolista Maurice Maeterlinck, autor cujos poemas também foram musicados por Nepomuceno. Os poemas de características parnasianas e simbolistas foram os prediletos dos franceses daquela época, muito provavelmente devido às novas possibilidades de relação entre música e texto.

O Parnasianismo e o Simbolismo surgiram na segunda metade do século XIX, em um período de predomínio do cientificismo e do positivismo. O Parnasianismo surgiu como uma reação à liberdade e aos excessos sentimentais dos românticos, defendendo a objetividade, a imparcialidade, o acentuado descritivismo, o culto de formas poéticas perfeitas, do purismo vocabular e linguístico, o erotismo e a sensualidade feminina, incluindo referências à mitologia greco-latina, tendo a obra como resultado do trabalho árduo do poeta. Na França, por exemplo, destacam-se Charles Baudelaire (1821-1867) e Mallarmé, os quais, no entanto, mais tarde, romperiam com a estética parnasiana em favor da simbolista. No Brasil, o principal nome é Olavo Bilac (1865-1918), que valorizou o cuidado formal do poema, em busca de palavras raras, rimas ricas e rigidez das regras da composição poética. Escreveu sobre temas greco-romanos, 
fez várias descrições da natureza, indicando uma herança romântica. Grande parte dos poemas é de sonetos e, diferentemente de outros poetas parnasianos, a poesia de Bilac apresenta uma postura intimista e subjetiva. O Parnasianismo foi o estilo oficial no final do século XIX e início do século XX até a Semana de Arte Moderna, quando os modernistas chegaram para destruir a tradição do século XIX. Apesar do progresso científico favorecer o rompimento do poeta ou a poesia com o passado (Castello 2004, p. 291), ao contrário do que ocorreu na Europa, o Parnasianismo no Brasil ainda carregou algumas características românticas.

Simultaneamente ao Parnasianismo, surge o Simbolismo, que em certo sentido pretendeu ser o oposto do Parnasianismo. Os simbolistas se voltaram para o íntimo e para a alma por meio do subjetivismo, da musicalidade, do místico, da religiosidade, da transcendência e do efeito de sugestão. $O$ movimento surge como uma reação ao materialismo predominante no final do século XIX, resultado da crença no cientificismo da época. Na França, dentre os grandes autores simbolistas estão Baudelaire, dissidente do Parnasianismo, Paul Verlaine (1844-1896) e Maeterlinck. No Brasil, o Simbolismo teve início em 1893 com a publicação de Missal e Broquéis de João da Cruz e Sousa (1861-1898), considerado por vários historiadores também o marco inicial do Modernismo no Brasil. Nesse ponto, é importante ressaltar que vários simbolistas foram dissidentes do Parnasianismo, inclusive o próprio Cruz e Sousa (Castello 2004, p. 346). O predomínio dos parnasianos nos grandes centros, no entanto, contribuiu para que os poetas simbolistas fossem praticamente ignorados naquele momento. Alguns críticos literários afirmam que o fim da era parnasianasimbolista ocorreu em 1902, com a publicação do livro Os Sertões, de Euclides da Cunha; outros, porém, dizem que terminou com a Semana de Arte Moderna, em 1922. Embora o Simbolismo não tenha conseguido substituir os grandes cânones da literatura oficial Parnasiana, ele seria retomado na década de 1930 por grandes poetas do Modernismo, como Carlos Drummond de Andrade (1902-1987), Cecília Meireles (1901-1964), Vinicius de Moraes (1913-1980), Mario Quintana (1906-1994). O Parnasianismo, que teve seu valor naquela época, hoje está quase que totalmente esquecido.

É sabido que os nossos grandes poetas modernistas, a serem consagrados, estão enraizados nesses antecedentes parnasianos e simbolistas [...]. Conheceram as formas tradicionais sob o esmero da linguagem parnasiana e 
Relações Intertextuais entre Canções de Nepomuceno sobre Poemas Parnasianos e Simbolistas e a Mélodie Francesa: Coração triste e Canção da ausência

as renovações simbolistas com a musicalidade da palavra (Castello 2004, p. 25).

\section{Metodologia}

Para Klein (2005, p. 3), o estudo da intertextualidade em música ainda é um campo pouco explorado e o seu estudo se mostra de grande valia para a musicologia, especialmente se considerado o papel essencial da intertextualidade tanto para compreensão como para a criação musical. Entretanto, embora alguns possam facilmente pensar que se trata apenas de procurar analogias e contrastes, é necessário destacar que a análise intertextual em música é complexa e requer a aplicação de uma metodologia cuidadosa, especialmente que dê conta de mostrar conexões e elementos menos aparentes. O processo analítico será baseado no estudo comparativo entre obras e não se furtará, no entanto, à identificação de aspectos que possam contribuir à caracterização do estilo composicional de Nepomuceno, tendo como referencial teórico básico Klein (2005), Straus (1990) e Reynolds (2003) para a análise das relações intertextuais e Stein e Spillman (1996) para a análise das relações entre música e texto. $\mathrm{Na}$ análise musical, incluímos a teoria dos conjuntos apresentada em Straus (2013) no estudo dos motivos.

\section{Coração triste}

Coração triste foi publicada em 1903, escrita sobre o poema do carioca Joaquim Maria Machado de Assis (1839-1908), intitulado Coração triste falando ao sol, inspirado em poema de Su-Tchon, poeta chinês que provavelmente viveu nos séculos X-XI, embora até hoje não tenha sido comprovada a sua existência (Jackson 2015, p. 311; Pinto 2013, p. 97). Machado de Assis é sempre lembrado por ser o representante brasileiro do realismo, mas sua obra costuma ser dividida em duas partes: uma primeira romântica e uma segunda realista. Coração triste falando ao sol foi escrita na primeira fase e faz parte da Lira Chinesa, coleção de oitos poemas inspirados em poemas de seis diferentes poetas chineses, publicada no volume Phalenas (Assis 1870, p. 111-112).

Os poemas imitados n'esta colleção [sic] são todos contemporâneos. Encontrei-os no livro publicado em 1868 pela Sra. Judith Walter, distincta [sic] viajante que dizem conhecer profundamente a lingua chineza [sic], e que traduziu em simples e corrente prosa (Assis 1870, p. 251). 
MUSICA THEORICA Revista da Associação Brasileira de Teoria e Análise Musical 2020,

v. 5, n. 1, p. 242-277 - Journal of the Brazilian Society for Music

Le livre de Jade (1868) é o livro de poemas chineses traduzidos para o francês por Judith Walter, pseudônimo de Judith Gautier (1845-1917), poetisa francesa, filha do famoso poeta francês Théophile Gautier (1811-1872). Apesar da inspiração em Gautier, características machadianas podem ser identificadas no poema, cuja escansão é apresentada no Quadro 1.

\begin{tabular}{|c|c|c|c|c|c|}
\hline Estrofes & Versos & & Rimas & $\begin{array}{l}\text { Quantidades } \\
\text { sílabas }\end{array}$ & Terminação \\
\hline \multirow{4}{*}{1} & 1 & No arvoredo sussurra_o vendaval do outono, & $a$ & 12 & Fraca \\
\hline & 2 & Deita as folhas à terra,_onde não há florir & $b$ & 12 & Forte \\
\hline & 3 & E eu contemplo sem pena_esse triste abandono; & $a$ & 12 & Fraca \\
\hline & 4 & Só eu as vi nascer, vejo-as só eu cair. & $b$ & 12 & Forte \\
\hline \multirow{4}{*}{2} & 5 & Como a escura montanha,_esguia e pavorosa & $c$ & 12 & Fraca \\
\hline & 6 & Faz, quando o sol descamba,_o vale anoitecer, & $d$ & 12 & Forte \\
\hline & 7 & A montanha da alma,_a tristeza amorosa, & $c$ & 12 & Fraca \\
\hline & 8 & Também de ignota sombra_enche todo o meu ser. & $d$ & 12 & Forte \\
\hline \multirow{4}{*}{3} & 9 & Transforma o frio inverno_a água em pedra dura, & $e$ & 12 & Fraca \\
\hline & 10 & Mas torna a pedra em água_um raio de verão; & $f$ & 12 & Forte \\
\hline & 11 & Vem, ó sol, vem, assume_o trono teu na altura, & $e$ & 12 & Fraca \\
\hline & 12 & Vê se podes fundir meu triste coração. & $f$ & 12 & Forte \\
\hline
\end{tabular}

Quadro 1: escansão poética de Coração triste falando ao sol

O poema é marcado pela regularidade e pelo rigor formal, o que parece aproximar o poema das características parnasianas. Um traço marcante é o uso de um tipo específico de verso dodecassílabo, o verso alexandrino clássico, cujo rigor técnico exige: (1) divisão do verso em dois hemistíquios, com sílabas átonas nas 6a e 12a sílabas do verso, (2) a 6a sílaba átona do primeiro hemistíquio deve ser ou a última sílaba de uma palavra oxítona ou a penúltima sílaba de uma palavra paroxítona (neste caso, o segundo hemistíquio deve iniciar com uma vogal, que será unida por elisão à última sílaba do primeiro hemistíquio), (3) evitar a sílaba átona do primeiro hemistíquio em uma palavra proparoxítona ou paroxítona com terminação em consoante. Machado de Assis foi o primeiro poeta brasileiro a usar essa forma trabalhosa de versificação, e a usou de forma extensiva em seus poemas. Neste poema, todos os versos podem ser enquadrados nas regras 1 e 2, a maior parte dos versos com a sílaba átona do 
Relações Intertextuais entre Canções de Nepomuceno sobre Poemas Parnasianos e Simbolistas e a Mélodie Francesa: Coração triste e Canção da ausência

primeiro hemistíquio na penúltima sílaba de uma palavra paroxítona (com o segundo hemistíquio iniciando na vogal); os dois únicos momentos em que a sílaba átona do primeiro hemistíquio está na última sílaba de uma palavra oxítona são no último verso da primeira estrofe e no último verso da terceira estrofe, criando uma sensação de equilíbrio entre essas duas estrofes, uma inicial e outra final. Somam-se ainda ao rigor dos versos alexandrinos, as rimas e terminações intercaladas.

O poema tem uma persona, ${ }^{4}$ o eu-lírico. Com exceção dos versos 11-12, nos quais o eu-lírico dirige as suas palavras ao sol, nos demais versos não há um modo de endereçamento ${ }^{5}$ claro; talvez o eu-lírico esteja falando para a audiência ou com ele mesmo, em um momento introspectivo, neste caso um tipo de solilóquio. O eu-lírico projeta os sentimentos ao descrever de modo melancólico o outono, estação de transição entre o verão e o inverno, em que as árvores perdem as suas folhas, os dias são mais curtos, os ventos mais fortes e as temperaturas mais baixas. A solidão e a tristeza do eu-lírico são intensificadas por Nepomuceno na repetição da súplica "enche todo o meu ser". Em um momento breve de claridade e esperança, tem-se as imagens de "um raio de verão" e do "sol" (v. 10-11), retornando a melancolia do "triste coração" no verso final do poema. O pessimismo, aliás, é um elemento recorrente nas obras de Machado de Assis.

A canção está em Ré menor, com o trecho intermediário contrastante em Fá\# menor, estabelecendo um contorno ABA', cada seção correspondendo a uma estrofe poética. As frases vocais são regulares, de quatro compassos, ampliadas em alguns pontos estruturais importantes pelo acréscimo de compassos solo do piano: arpejo do acorde de tônica na introdução (c. 1-2), arpejo do acorde de dominante na finalização da seção A (c. 19), antecipação da frase vocal final (c. 53) e arpejo final do acorde de tônica (c. 58). A linha vocal é relativamente simples e homogênea, com extensão do Ré4 ao Sol5 (nota mais aguda no c. 37, na repetição de "enche todo o meu ser") e sugestão modal pela escassez da sensível. A parte do piano dobra a linha vocal na maior parte do tempo.

\footnotetext{
${ }^{4}$ Persona é quem fala no poema e na canção (Stein e Spillmann 1996, p. 330)

${ }^{5}$ Modo de endereçamento é a quem a persona fala no poema e na canção (Stein e Spillmann 1996, p. 329).
} 
As cadências de finalização seccional realçam os três momentos de maior intimismo do eu-lírico (versos em que a persona fala na primeira pessoa): na finalização da seção $\mathrm{A}$, a cadência à dominante em Ré menor intensifica "vejo-as só eu cair" (c. 17-19); na finalização da seção B, a modulação de retorno de Fá\# menor para Ré menor intensifica as duas vezes de "enche todo o meu ser" (c. 3538); e na finalização da canção, a cadência autêntica imperfeita em Ré menor intensifica "o meu triste coração" (c. 56-58).

A canção começa com uma introdução do piano de dois compassos em arpejos ascendentes do acorde de tônica (Ré menor), preparando o c. 3, em que a parte do piano inicia um pouco antes da linha vocal uma melodia na voz mais aguda, contendo os dois motivos mais recorrentes ao longo da canção: o motivo a, caracterizado pela repetição inicial de três notas, seguindo um intervalo descendente de terça maior, e o motivo $b$, representado por uma apojatura descendente de segunda maior, conforme Ex. 1.

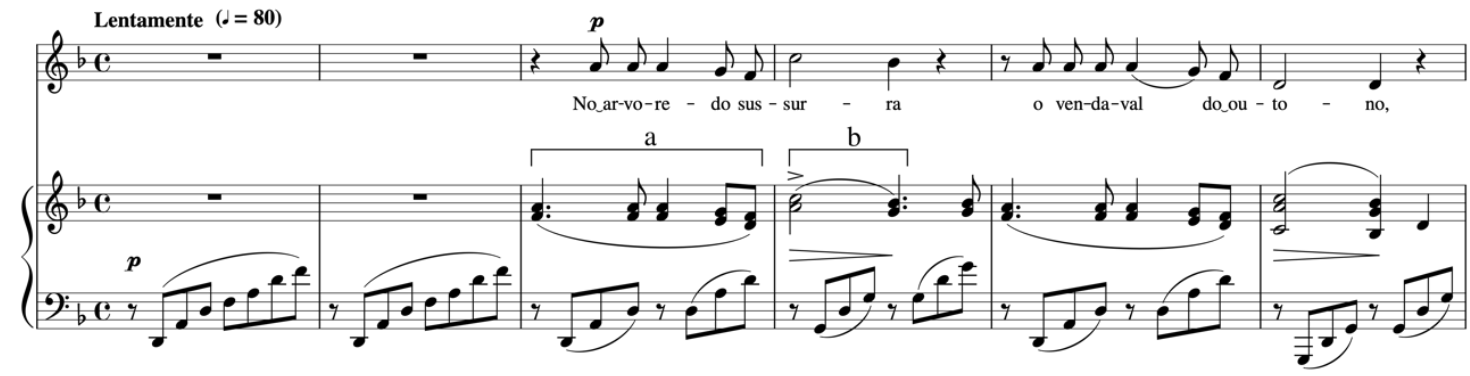

Exemplo 1: Coração triste, c. 1-6

A apojatura do motivo b é um elemento recorrente em Coração triste e sua implicação dramática pode ser inferida pela relação com o texto. A primeira ocorrência da apojatura na canção (c. 4) é enfatizada por um acento na parte do piano, em "sussurra". Apenas em outro momento a apojatura é novamente indicada com acento (c. 10), em "florir", também na seção A. A ênfase nessas apojaturas iniciais intensifica a combinação do sussurro do vento com a ausência do florir (possivelmente representando a melancolia do presente e a saudade do passado). Quando a persona chama pelo sol, na seção A' (c. 47-52), o motivo b cessa por um momento, mas quando a persona diz "vê se podes fundir o meu triste coração" (c. 54), o motivo b retorna, intensificado pela indicação "com tristeza", conforme Ex. 2. O efeito mais dramático do motivo b ocorre na cadência final, em "triste coração", enfatizado pelo choque Dó\#-Dół. 
Relações Intertextuais entre Canções de Nepomuceno sobre Poemas Parnasianos e Simbolistas e a Mélodie Francesa: Coração triste e Canção da ausência

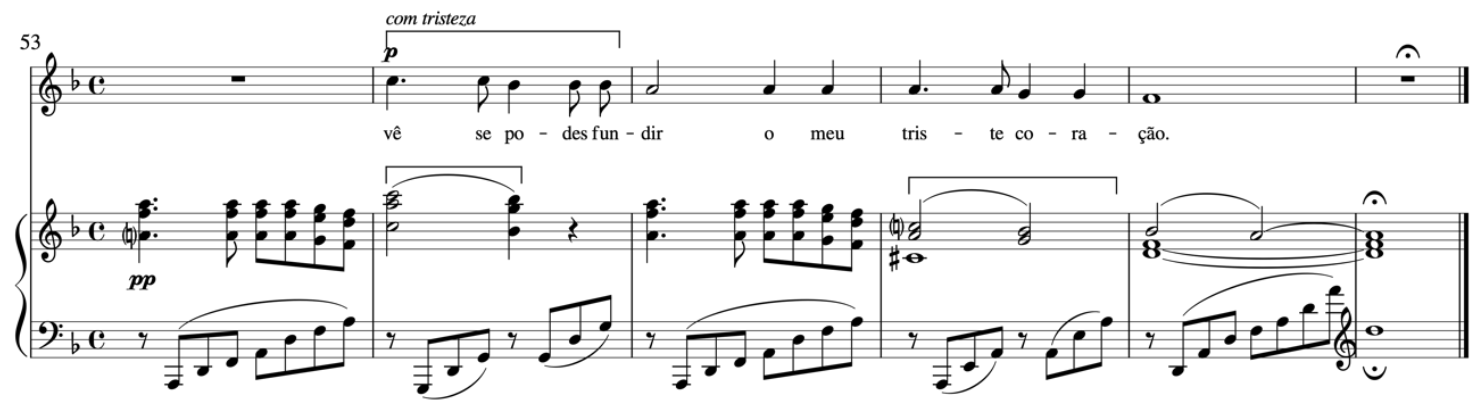

Exemplo 2: Coração triste, c. 53-58

É interessante notar que a primeira variedade do motivo a, na primeira entrada da linha vocal (c. 3), é única ao longo da canção. Em nenhum outro momento o motivo a reaparece com a mesma identidade rítmica. A peculiaridade da primeira entrada do motivo a na linha vocal remete a uma outra canção, Mai, de Fauré, conforme o Ex. 3. Enquanto o motivo a é facilmente visualizado na linha vocal do c. 3, o motivo b é mais difuso, parecendo uma combinação de "fleurs dans les" e "-clamé".

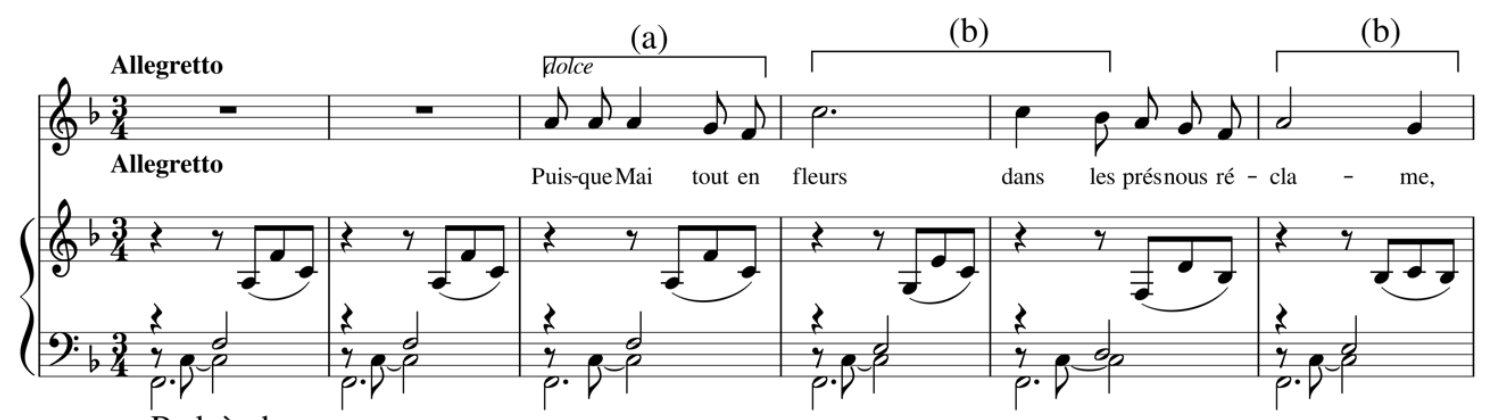

Ped. à chaque measure

Exemplo 3: Mai, c. 1-6

Mai é a segunda obra na lista de composições de Fauré, escrita quando Fauré tinha 17 anos de idade e ainda estudava na École Niedermeyer, sob a tutela de Saint-Saëns. O poema é de Victor Hugo (1802-1885), principal expoente do romantismo francês, publicada em 1871 (mais de vinte anos antes da publicação de Coração triste). O poema é dado a seguir (seguido de uma tradução nossa):

Puisque mai tout en fleurs dans les prés nous réclame,

Viens! ne te lasse pas de meler à ton âme

La campagne, les bois, les ombrages charmants,
Porque maio, na sua plena floração, aos prados nos chama,

Venha! Não se canse de misturar à tua alma

O campo, a floresta, as sombras encantadoras, 
MUSICA THEORICA Revista da Associação Brasileira de Teoria e Análise Musical 2020, v. 5, n. 1, p. 242-277 - Journal of the Brazilian Society for Music

Theory and Analysis @ TeMA 2020 - ISSN 2525-5541

Les larges clairs de lune au bord des flots dormants,

Le sentier qui finit où le chemin commence,

Et l'air et le printemps et l'horizon immense,

L'horizon que ce monde attache humble et joyeux

Comme une lèvre au bas de la robe des cieux!

Viens! et que le regard des pudiques étoiles

Qui tombe sur la terre à travers tant de voiles,

Que l'arbre pénétré de parfums et de chants,

Que le souffle embrasé de midi dans les champs,

Et l'ombre et le soleil et l'onde et la verdure,

Et le rayonnement de toute la nature

Fassent épanouir, comme une double fleur,

La beauté sur ton front et l'amour dans ton cour!
Os vastos luares nas margens de águas adormecidas

O caminho que termina onde a estrada começa,

E o ar e a primavera e o imenso horizonte,

O horizonte ao qual este mundo está ligado humilde e alegre,

Como uma aba na barra do manto do céu!

Venha! E possa o olhar das castas estrelas,

Que tomba sobre a terra através de muitos véus,

Possa a árvore mergulhada em perfume e de canções,

Que o ardente fôlego do meio-dia no campo,

E a sombra e o sol e a onda e a vegetação,

E o esplendor de toda a natureza

Que eles floresçam, como uma flor dupla,

A beleza em tua fronte e o amor em teu coração!

O eu-lírico exalta as belezas de maio, justamente um dos meses em que ocorre o outono no Brasil. Entretanto, ao contrário de Coração triste, que descreve o lado frio e escuro do outono, o poema de Victor Hugo exalta as belezas da primavera na França, época em que a natureza renasce com todo o seu esplendor, calor e beleza, quando o canto dos pássaros e todos os elementos da natureza contribuem para um sentimento de euforia, otimismo e alegria pelo futuro promissor, um período que também representa a promessa de amor (Stein e Spillman 1996, p. 22).

A euforia e o entusiasmo do eu-lírico, que chama a sua amada para desfrutar das belezas da primavera, são enfatizados com uma música serena e tranquila, mas que também denota alguma ambiguidade. Para Graham Johnson (2009, p. 41), a combinação do exagerado entusiasmo romântico de Victor Hugo e do pouco extrovertido Fauré são o principal desafio na interpretação desta canção.

Assim como em Coração triste, o fraseado em Mai é regular, de quatro compassos, também incluindo alguns compassos de piano solo adicionados em pontos estruturais importantes, como na introdução, arpejo do acorde de tônica (c. 1-2), no final da seção A, arpejo do acorde de dominante (c. 35) e poslúdio, arpejo do acorde de tônica (c. 68-69). A linha vocal também é relativamente simples e homogênea, com as notas mais grave e mais aguda enfatizando momentos de maior intimismo e euforia do eu-lírico, respectivamente: a nota 
Relações Intertextuais entre Canções de Nepomuceno sobre Poemas Parnasianos e Simbolistas e a Mélodie Francesa: Coração triste e Canção da ausência

mais grave (Si3, c. 9) enfatiza "ton âme" ("tua alma") e a nota mais aguda (Fá5, c. 31 e 64) enfatiza "une lèvre" ("uma aba") e "beauté" ("beleza"). Outro elemento que sugere similaridade entre as peças é o acompanhamento arpejado do piano, em movimentos ascendentes, da mão esquerda para a mão direita. Ao contrário do que ocorre em Coração triste, porém, a parte mais aguda do piano não dobra a linha vocal (o dobramento da linha vocal na parte do piano em Coração triste contribui para enfatizar os motivos e fortalece a alusão à canção de Fauré). Mas além das sugestivas similaridades, as canções também se destacam pelas diferenças peculiares, conforme Quadro 2.

\begin{tabular}{|l|l|l|}
\cline { 2 - 3 } \multicolumn{1}{l|}{} & Coração triste & Mai \\
\hline Tonalidade & Ré menor & Fá maior \\
\hline Forma & ABA' $^{\prime}$ & AA' $^{\prime}$ \\
\hline Fórmula de compasso & $4 / 4$ & $3 / 4$ \\
\hline Andamento & Lentamente & Allegretto \\
\hline
\end{tabular}

Quadro 2: elementos distintos entre Coração triste e Mai

As diferenças, porém, não enfraquecem uma possível relação entre ambas as canções. Pelo contrário, ajudam a fortalecer a alusão na medida em que é possível deduzir uma preocupação de Nepomuceno em estabelecer relações com um texto cujas imagens refletem justamente o oposto do que foi dito no outro poema. Na canção de Nepomuceno, por exemplo, os versos de maior intimismo (primeira pessoa) são enfatizados ao final das seções, o que poderia ser associado com o sentimento de desesperança do eu-lírico. Na canção de Fauré, por outro lado, o início das duas seções enfatiza os momentos eufóricos do eu-lírico em que ele chama a pessoa amada para desfrutar das belezas da primavera, momentos que remetem à esperança do eu-lírico. A forma estrófica de Fauré, tipo ritornello, revela a influência inicial de Gounod (Nectoux 1991, p. 64). Nepomuceno, por outro lado, escolhe uma forma ternária, que traz de volta os sentimentos iniciais. A euforia e o entusiasmo de Mai podem ter inspirado o tom melancólico e esperançoso de Coração triste, ambas as canções tendo a natureza como reflexo de sentimentos íntimos do eu-lírico. A alusão musical de Coração triste à Mai cria também uma alusão poética entre ambos os poemas. A impressão é que as belezas e a esperança de renascimento da vida e do amor da primavera de Mai 
são o motivo de resistência e esperança do eu-lírico de Coração triste, em meio ao frio e a melancolia do outono.

$\mathrm{Na}$ possível relação de alusão entre Coração triste e Mai, podemos identificar algumas estratégias intertextuais: motivização, no uso e na ênfase de um motivo pré-existente (Straus 1990, p. 17), modelagem, que é o uso de uma obra ou parte de obra pré-existente, seja material melódico, forma ou outros elementos que possam ser imitados, para a elaboração de uma nova estrutura (Burkholder 1994, p. 855), e alusão contrastante, que ocorre quando um motivo é extraído de seu contexto original e inserido em um novo contexto, com a intenção de distanciar o motivo de sua fonte original e estabelecer um novo significado (Reynolds 2003, p. 21). Assim como Machado de Assis inspirou-se nas traduções de Gautier, Nepomuceno parece ter buscado inspiração em Mai para escrever a sua canção Coração triste.

\section{Canção da ausência}

Uma outra canção que será destacada pelas alusões a outras obras é Canção da ausência, datada de 1915 e escrita sobre o poema Último Idílio do sergipano Hermes Fontes (1888-1930), dissidente parnasiano e um dos principais representantes do Simbolismo brasileiro. A poesia de Hermes Fontes é conhecida pela profunda melancolia, resultado das desilusões políticas e amorosas que marcaram a vida do poeta até o seu suicídio na noite de Natal de 1930. Foi um poeta consagrado a seu tempo, mas que atualmente encontra-se no esquecimento (Fontes 2011, p. 1).

\section{Último Idílio}

Uma Lua religiosa,

uma Lua romanesca,

aponta como uma rosa

muito branca, muito fresca,

no ar sem fim.

Ah! quem me dera essa rosa

para eu dá-la ao teu Jardim?!

Um luar sereno e belo,

fluido mármore da altura 

Poemas Parnasianos e Simbolistas e a Mélodie Francesa: Coração triste e Canção da ausência

parece esculpir o estelo para a minha sepultura consagrar:

Ah! quem me dera esse estelo para enfeite do teu lar?!

Do alto, a Lua paraninfa Terra e Céu noivando... e verte pranto argênteo, clara ninfa Sobre a Natureza inerte, sem vigor:

Ah! quem me dera essa linfa para o teu banho de flor!?...

Dolorosa, fria Lua,

Pia e búrnea da alta Ermida! Fonte grega: Estátua nua! Rosa branca, refletida nas marés!

Ah! Quem me dera ser Lua para esfolhar-me aos teus pés!...

O eu-lírico dirige as suas palavras a uma pessoa a quem ele ama e anseia estar perto. O poema tem oito estrofes: quatro estrofes maiores (cinco versos) e quatro estrofes menores (dois versos), cada estrofe menor como uma reação à estrofe maior anterior. Com exceção da segunda estrofe maior, as demais estrofes maiores são escritas na terceira pessoa (distante, amplo, impessoal, coletivo); na segunda estrofe maior e nas quatro estrofes menores, o eu-lírico fala na primeira pessoa do singular (próximo, limitado, intimista, pessoal). A ênfase em cores pálidas e aparência inerte de elementos religiosos, de natureza morta e da mitologia, bem como em imagens de elementos negativo ("sepultura", "ornamento de altar", "sem vigor", "dolorosa"), remete ao parnasianismo e intensifica a melancolia e a solidão do eu-lírico. As recorrentes expressões "quem 
me dera" manifestam desejos do eu-lírico que, ao que parece, não podem ser realizados.

A canção está dividida em quatro seções, $\mathrm{ABCD}$, lembrando a tradicional forma do Lied, through composed. ${ }^{6}$ Embora a armadura de clave indique Mi, maior ou Dó menor, nenhuma das duas tonalidades é confirmada de modo consistente, a não ser no final da canção (c. 61-65), em que Mi, maior é enfatizada por arpejos da tríade na linha vocal e na parte do piano, no momento de maior anseio e intimismo do eu-lírico (não fosse pela ausência da nota Fá, a escala de Mi, estaria completa).

A escala de tons inteiros é uma figura peculiar e recorrente em Canção da ausência. A versão Dó-Ré aparece completa nos c. 1-6 (exceto pela nota Sol na linha vocal do c. 6, que aparece como nota de passagem entre Lá, e Fá\#), 16-24 e 46-56. Nas três ocorrências, há uma clara ênfase motívica no tricorde (024), caracterizado por dois tons inteiros consecutivos, os quais também caracterizam o motivo a de Coração triste. O Ex. 4 mostra as ocorrências do tricorde (024) nos compassos iniciais da canção: Dó-Si-Láb (azul), Ré-Mi-Fá\# (vermelho), Dó-RéMi (verde) e Ré-Dó-Si, (amarelo), incluindo repetições (linhas pontilhadas). As setas indicam trítonos realçados nas entradas da parte do piano e da linha do vocal (em relação à parte do piano).

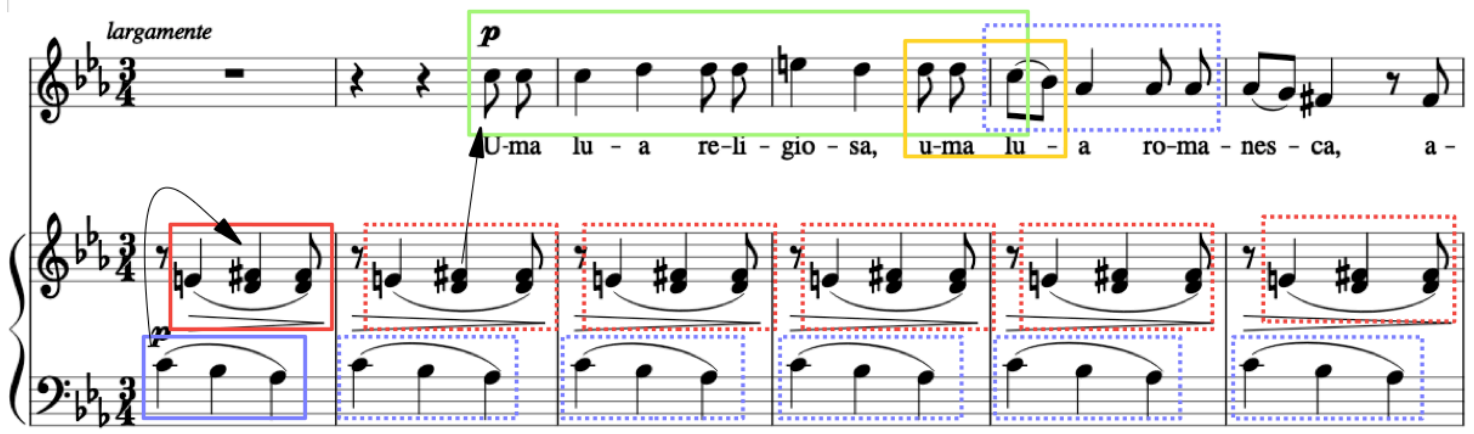

Exemplo 4: Canção da ausência, c. 1-6

O Ex. 5 mostra a segunda ocorrência da escala de tons inteiros, no início da seção B, com a parte do piano no registro mais agudo intensificando a imagem

\footnotetext{
${ }^{6}$ Termo em inglês para durchkomponiert, termo alemão usado para denotar o contorno formal em que um Lied não apresenta uma repetição consistente; antes, apresenta um poema com uma clara estória ou uma progressão poética em movimento para a frente. A coerência musical é criada ocasionalmente pela repetição motívica (Stein e Spillman 1996, p. 335).
} 
Relações Intertextuais entre Canções de Nepomuceno sobre Poemas Parnasianos e Simbolistas e a Mélodie Francesa: Coração triste e Canção da ausência

poética de alto e amplo ("altura" e "luar"), novamente com realces do tricorde (024), incluindo um novo agrupamento de notas, Mi-Fá\#-Sol\# (ciano).

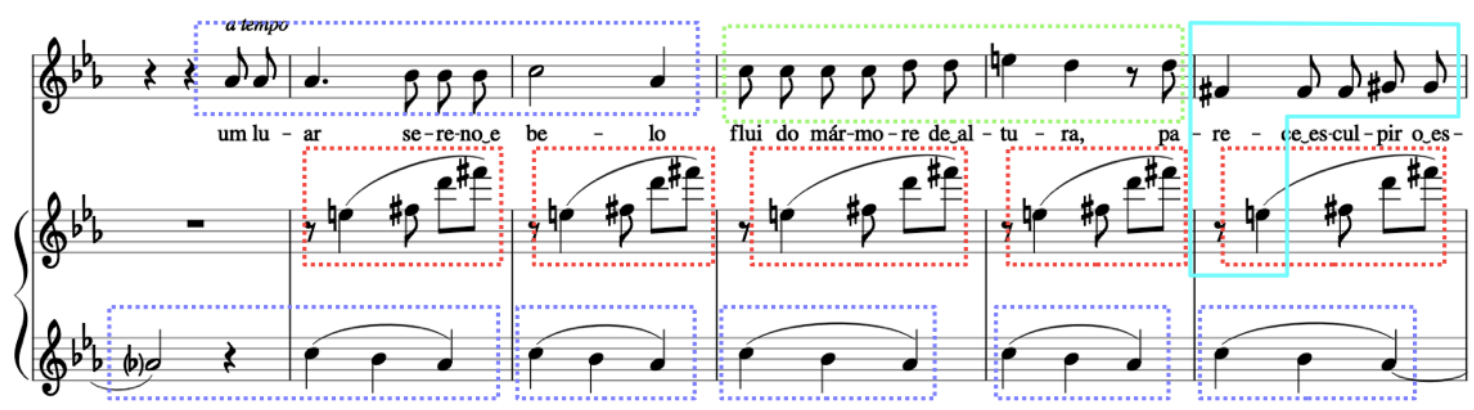

Exemplo 5: Canção da ausência, c. 16-21

O Ex. 6 mostra a terceira ocorrência da escala de tons inteiros, no início da seção D. O registro é contraído como nos compassos iniciais (incluindo retorno da parte do piano dos c. 1-6 nos c. 49-54), incluindo um novo agrupamento de notas, Sol,- -Lá,$-S i$, (rosa), novamente com o trítono inicial entre a linha vocal e a parte do piano (seta).

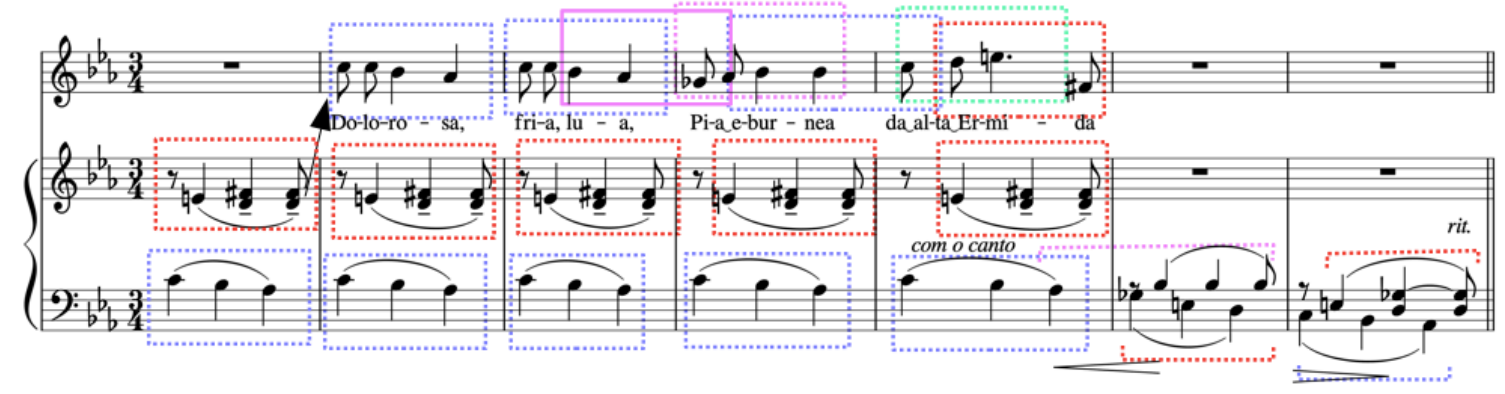

Exemplo 6: Canção da ausência, c. 50-56

A recorrência do tricorde (024), tanto na Canção da ausência como em Coração triste, evoca um motivo peculiar de Fauré, considerado um tipo de assinatura do compositor (Johnson 2009, p. 65). Segundo Nectoux (1991, p. 231), apesar de não ter explorado a escala de tons inteiros tão intensamente como Debussy, Fauré tinha uma predileção por melodias em tons inteiros. O motivo ocorre pela primeira vez na canção Lydia, publicada em 1817 e escrita sobre poema do parnasiano Leconte de Lisle (1818-1894), dado a seguir (seguido de uma tradução nossa).
Lydia
Lydia
Lydia, sur tes roses joues,
Lydia, em suas bochechas rosadas,
Et sur ton col frais et si blanc
E no seu pescoço fresco e tão branco, 
MUSICA THEORICA Revista da Associação Brasileira de Teoria e Análise Musical 2020, v. 5, n. 1, p. 242-277 - Journal of the Brazilian Society for Music

Theory and Analysis @ TeMA 2020 - ISSN 2525-5541

Roule étincelant

L'or fluide que tu dénoues.

Le jour qui luit est le meilleur:

Oublions l'éternelle tombe.

Laisse tes baisers de colombe

Chanter sur tá lèvre en fleur.

Un lys caché répand sans cesse

Une odeur divine en ton sein :

Les délices, comme un essaim,

Sortent de toi, jeune déesse!

Je t'aime et meurs, ô mes amours!

Mon âme en baisers m'est ravie.

Ô Lydia, rends-moi la vie,

Que je puisse mourir toujours!
Rola cintilante

O ouro fluido que você derrama.

O dia que desponta é o melhor:

Esqueçamos a sepultura eterna.

Deixa os teus beijos de pomba

Cantar nos teus lábios em flor.

Um lírio escondido derrama sem cessar

Uma fragrância divina em seu peito:

As delícias, como um enxame,

Fluem de você, jovem deusa!

Eu te amo e morro, ó meu amor!

Minha alma em beijos me é roubada.

Ó Lydia, dê-me minha vida novamente,

Para que eu possa morrer para sempre!

O poema de Leconte de Lisle lembra o poema de Hermes Fontes no tom melancólico, no emprego do tema mitológico, incluindo o endeusamento da mulher, e na ênfase em cores pálidas, especialmente o branco, possivelmente indicando a ideia de amor impossível. O eu-lírico dirige as suas palavras a uma pessoa a quem ama e de quem ele quer estar perto (nem que seja na morte, no último verso). Referências ao passado, especialmente aos antigos mundos grego e romano, eram comuns tanto na poesia dos românticos como dos parnasianos. Os poetas viam no passado longínquo um meio de fuga das suas tormentas diárias e uma maneira de viver os seus amores impossíveis; imagens e temas das antigas Grécia e Roma eram usadas para dramatizar e intensificar sentimentos e elementos poéticos (Stein e Spillman 1996, p. 13). A morte tranquila como um meio de salvação da realidade opressiva também é uma característica romântica (Stein e Spillman 1996, p. 11). Lídia foi um reino importante na parte ocidental da Ásia menor, atual Turquia ocidental, cujo período de apogeu econômico ocorreu por volta do século VII A.C. Acredita-se que em Lídia foram cunhadas as primeiras moedas de ouro e de prata e que o nosso modo escalar lídio provém dessa região. A imagem da mulher idealizada, perfeita, casta e enigmática, de 
Relações Intertextuais entre Canções de Nepomuceno sobre Poemas Parnasianos e Simbolistas e a Mélodie Francesa: Coração triste e Canção da ausência

onde fluíam tesouros escondidos e inesgotáveis, combinava com as estátuas pálidas e etéreas do mundo antigo (Cavalcanti 2005, p. 21-22).

Lydia é considerada um divisor de águas entre as canções de Fauré, tanto em estrutura como na maior expressividade íntima, mostrando uma maior preocupação na escolha dos poemas (Nectoux 1991, p. 65). A atmosfera das antigas Grécia e Roma é resultado, como o próprio título parece indicar, do uso do modo lídio, ao qual Fauré recorre para compor o famoso motivo de Lydia (Johnson 2009, p. 64), apresentada nos primeiros compassos da linha vocal e dobrada na voz mais aguda da parte do piano. O primeiro fragmento da linha vocal, construído sobre as quatro primeiras notas do modo lídio, é o motivo que passou mais tarde ser considerado um tipo de assinatura ou tema de Fauré: um movimento sinuoso de três notas em intervalos de tom, subindo e descendo, e depois outro movimento ascendente, começando no segundo grau da escala, também em intervalos de tom. Em Lydia, Fauré usa a sua maestria com os modos eclesiásticos para criar uma música arrebatadora, combinando austeridade e doçura (Johnson e Stokes 2002, p. 163). Vemos uma nova concepção do papel do piano, estabelecendo um diálogo com a linha vocal, preservando a continuidade entre as duas partes na primeira estrofe e assumindo até o papel de liderança nas segunda e terceira estrofes (Nectoux 1991, p. 66). As quatro primeiras notas do modo lídio e o movimento de três notas consecutivas, contendo apenas intervalos de tom entre os seus membros, correspondem, respectivamente, ao tetracorde (0246) e ao tricorde (024), conforme Ex. 7. As setas indicam a concentração de trítonos no c. 4 ("tes roses joues"/ "suas bochechas rosadas").

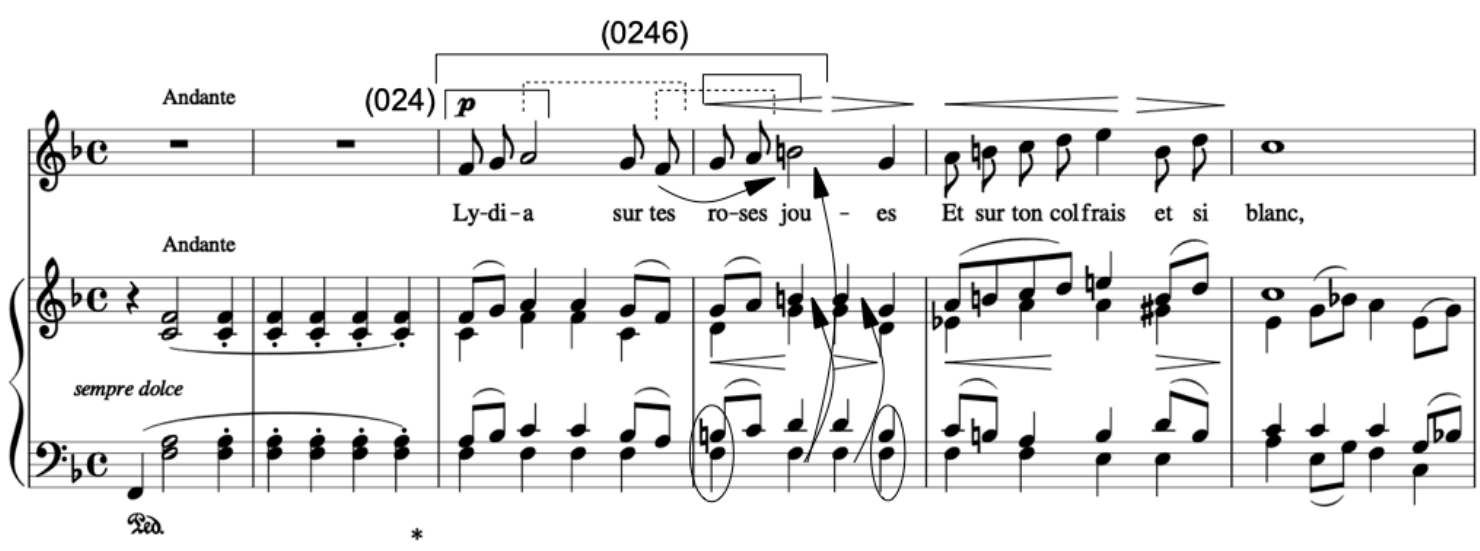

Exemplo 7: Lydia, c. 1-6

A Fig. 1 coloca os motivos de Lydia e Canção da ausência lado a lado. Ambos os motivos começam com o movimento de subida e descida, mas enquanto o 
MUSICA THEORICA Revista da Associação Brasileira de Teoria e Análise Musical 2020, v. 5, n. 1, p. 242-277 - Journal of the Brazilian Society for Music

motivo de Fauré segue com um movimento de subida, o motivo de Nepomuceno segue com um movimento oposto, de descida. A mudança de direção no motivo de Nepomuceno amplia e realça os elementos constituintes do motivo de Fauré, o que poderia ser descrito como uma estratégia de motivização (Straus 1990, p. 17). Interessante lembrar que o motivo a de Coração triste também corresponde a um tricorde (024), o que poderia ter também alguma relação com o motivo peculiar de Fauré.

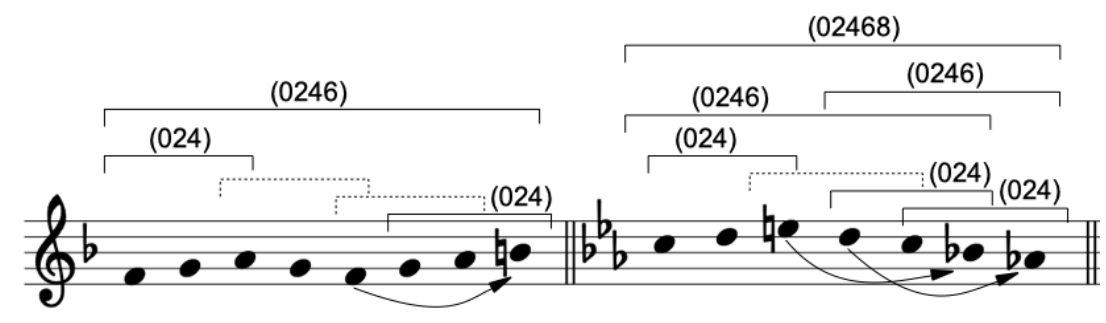

Figura 1: motivos em Lydia e Canção da ausência

O motivo de Lydia reaparece em várias outras obras de Fauré, de maneira clara ou apenas sugerida (Johnson 2016, p. 65). Destacaremos algumas, considerando a sugestiva relação com a canção de Nepomuceno: La Lune blanche e J'ai presque peur, en verité (Le Bonne chanson), L'aube blanche (La Chanson d'Ève) e L'absent.

La Lune blanche e J'ai presque peur, en verité, contidas no ciclo Le Bonne chanson, têm poemas de Paul Verlaine (1844-1896). O poema de La Lune blanche é apresentado a seguir (seguido de uma tradução nossa).

$\begin{array}{ll}\text { La Lune blanche } & \text { A lua branca } \\ \text { La lune blanche } & \text { A lua branca } \\ \text { Luit dans les bois; } & \text { Brilha na floresta; } \\ \text { De chaque branche } & \text { De cada ramo } \\ \text { Part une voix } & \text { Vem uma voz } \\ \text { Sous la ramée... } & \text { Sob a folhagem... } \\ & \\ \text { Ô bien-aimée. } & \text { Ó minha amada. } \\ & \\ \text { L'étang reflète, } & \text { A água reflete, } \\ \text { Profond miroir, } & \text { Espelho profundo, } \\ \text { La silhouette } & \text { A silhueta, } \\ \text { Du saule noir } & \text { Do salgueiro preto }\end{array}$


Relações Intertextuais entre Canções de Nepomuceno sobre Poemas Parnasianos e Simbolistas e a Mélodie Francesa: Coração triste e Canção da ausência

Où le vent pleure... $\quad$ Onde o vento está chorando...

Rêvons, c'est l'heure. Nos deixe sonhar, esta é a hora.

Un vaste et tendre Uma vasta e tenra

Apaisement Consolação

Semble descendre Parece cair

Du firmament Do céu

Que l'astre irise... Q Que a lua ilumina...

C'est l'heure exquise. Este é momento perfeito.

O poema enfatiza a melancolia do eu-lírico através da ênfase em elementos da natureza, como o brilho da lua na noite escura, o vento que chora, o salgueiro preto refletido no espelho profundo da água, e no sonho com a pessoa amada (novamente o amor impossível). Em La Lune blanche, o peculiar motivo de Lydia é ecoado na parte do piano, quando a persona fala sobre a voz que vem da folhagem, conforme Ex. 8. Note que o motivo é realçado como uma melodia independente na parte do piano. A relativa independência do tema pode ser um exemplo do que Reynolds (2003, p. 75) chama de alusão contrastante: quando uma alusão musical/poética contrasta dentro da nova composição, mas é semanticamente assimilável na composição anterior. Para Stein e Spillman (1996, p. 163-164), a presença de melodias independentes na parte do piano pode indicar a adição de personas diferentes na parte do piano. Neste caso, o eco do motivo de Lydia de maneira tão clara na parte do piano parece ter a função de reviver a imagem da amada referenciada em Lydia (La bonne chanson foi publicada em 1894, mais de vinte anos após Lydia), já que, segundo Fauré, o tema de Lydia se refere a uma cantora, embora nunca tenha revelado o nome dela (Nectoux 1991, p. 188). 
MUSICA THEORICA Revista da Associação Brasileira de Teoria e Análise Musical 2020, v. 5, n. 1, p. 242-277 - Journal of the Brazilian Society for Music

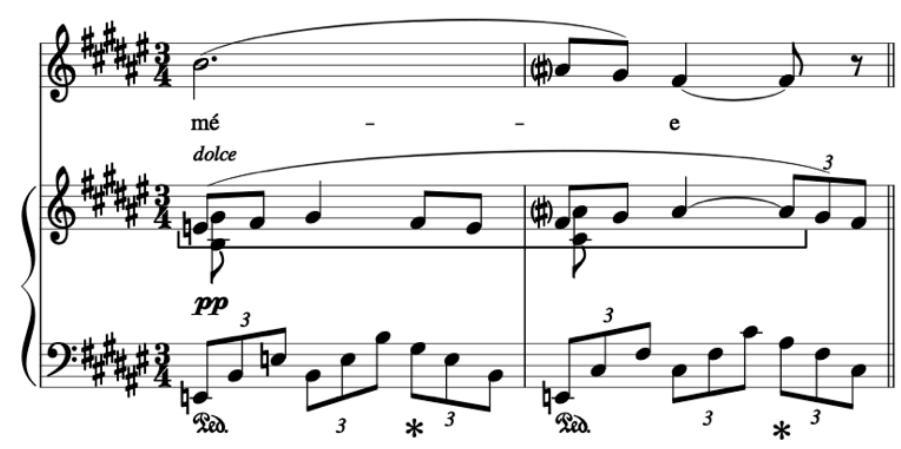

Exemplo 8: La Lune blanche, c. 9-10

O poema de J'ai presque peur, en verité é dado a seguir (seguido de uma tradução nossa).

J'ai presque peur, en vérité

J'ai presque peur, en vérité

Tant je sens ma vie enlacée

$A$ la radieuse pensée

Qui m'a pris l'âme l'autre été,

Tant votre image, à jamais chère,

Habite en ce coeur tout à vous,

[Mon]1 coeur uniquement jaloux

De vous aimer et de vous plaire;

Et je tremble, pardonnez-moi

$D^{\prime}$ aussi franchement vous le dire,

À penser qu'un mot, [un]2 sourire

De vous est désormais ma loi,

Et qu'il vous suffirait d'un geste,

D'une parole ou d'un clin d'oeil,

Pour mettre tout mon être en deuil

De son illusion céleste.

Mais plutôt je ne veux vous voir,

L'avenir dût-il m'être sombre

Et fécond en peines sans nombre,

$Q u^{\prime} a ̀$ travers un immense espoir,

\section{Estou quase com medo, na verdade}

Estou quase com medo, na verdade

Ao sentir minha vida enlaçada

Com um pensamento radioso

Que levou a minha alma no último versão,

Tão profundamente a tua tão querida imagem

Habita este coração que é todo seu,

Este coração, cujo único desejo

É te amar e te agradar;

E eu tremo, perdoe-me

Por falar tão sinceramente,

De pensar que uma palavra, um sorriso

De você agora é minha lei.

E que um gesto seria suficiente,

Uma palavra, one único olhar,

De afundar todo o meu ser em choro

Por esta celestial ilusão.

Mas eu preferiria não ver você,

Por mais obscuro que seja o futuro,

E cheio de incalculável pesar,

Eu não poderia, através de um imensa esperança, 
Relações Intertextuais entre Canções de Nepomuceno sobre Poemas Parnasianos e Simbolistas e a Mélodie Francesa: Coração triste e Canção da ausência

Plongé dans ce bonheur suprême

De me dire encore et toujours,

En dépit des mornes retours,

Que je vous aime, que je t'aime!
Envolvido nesta imensa alegria,

Repetir para mim de novo e de novo,

Apesar dos retornos sombrios,

Que eu amo você, que eu te amo!

Em J'ai presque peur, en verité, o eu-lírico declara o seu amor à pessoa amada, mas, pelo que sugere o texto, a pessoa amada já não está mais ao seu lado, pois a lembrança da pessoa amada o faz sofrer. Ele também teme e lamenta o seu futuro e chega até ao ponto de desejar não ter conhecido a pessoa, pois essa amada não estará lá. O motivo de Lydia é novamente ecoado na parte do piano quando o eu-lírico dirige as suas palavras à pessoa amada, conforme Ex. 9. Novamente o motivo de Lydia aparece de maneira distinta, como uma melodia independente na parte do piano, possivelmente enfatizando a alusão musical e sugerindo a presença de uma persona diferente na parte do piano.

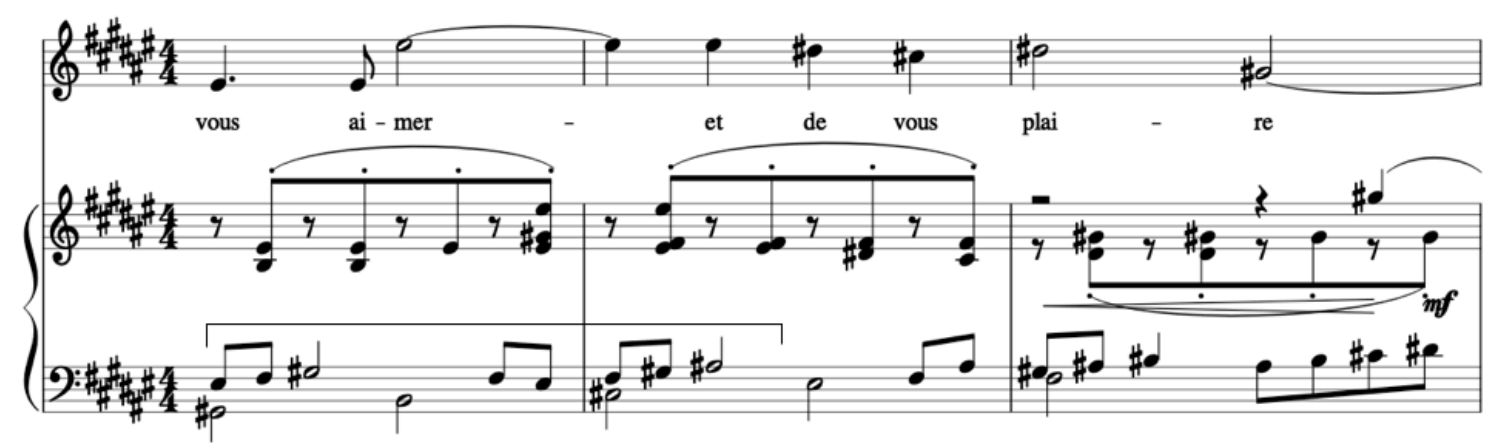

Exemplo 9: J'ai presque peur, en verité, c. 19-21

L'aube blanche é a quinta peça do ciclo La Chanson d'Ève, publicada em 1908 (depois de Le Bonne chanson e quase trinte anos após Lydia). O texto, apresentado a seguir (seguido de uma tradução nossa), é do simbolista belga Charles von Lerberghe (1861-1907).

L'aube blanche dit à mon rêve

L'aube blanche dit à mon rêve:

"Éveille-toi, le soleil luit".

Mon âme écoute et je soulève

Un peu mes paupières vers lui.

Un rayon de lumière touche

\section{O amanhecer branco diz ao meu sonho}

$\mathrm{O}$ amanhecer branco diz ao meu sonho:

"Desperte, o sol está brilhando".

Minha alma escuta e eu me levanto

Minhas pálpebras levemente em direção a ele. 
MUSICA THEORICA Revista da Associação Brasileira de Teoria e Análise Musical 2020, v. 5, n. 1, p. 242-277 - Journal of the Brazilian Society for Music

Theory and Analysis @ TeMA 2020 - ISSN 2525-5541

La pâle fleur de mes yeux bleus;

Une flamme éveille ma bouche,

Un souffle éveille mes cheveux.

Et mon âme, comme une rose

Tremblante, lente, tout le jour,

S'éveille à la beauté des choses,

Comme mon coeur à leur amour.

\begin{abstract}
A flor pálida dos meus olhos azuis;
Uma chama desperta minha boca,

Uma brisa desperta meu cabelo.
\end{abstract}

E minha alma, como uma rosa,

Tremendo e apática o dia todo,

Desperta para a beleza das coisas,

Como o meu coração ao seu amor.

Novamente um poema que fala sobre o futuro, um futuro que chama pelo eu-lírico, mas ele não parece muito entusiasmado, pois demora a se levantar. Ele diz que desperta para a beleza das coisas assim como o seu coração desperta para o amor da pessoa amada. A falta de entusiasmo do eu-lírico, no entanto, pode indicar que a sua amada não está presente ou até que o seu amor não é correspondido. Nesta peça, o motivo de Lydia é sugerido de maneira mais difusa, com a melodia da linha vocal integralmente composta sobre uma escala de tons inteiros completa, o que pode representar a de uma memória ainda mais longínqua, mas não menos ressonante. No Ex. 10, é possível ver o longo movimento descendente em tons inteiros da linha vocal. A alusão ao motivo de Lydia ocorre quando o eu-lírico fala que a natureza o desperta, trazendo à memória a imagem da pessoa amada.

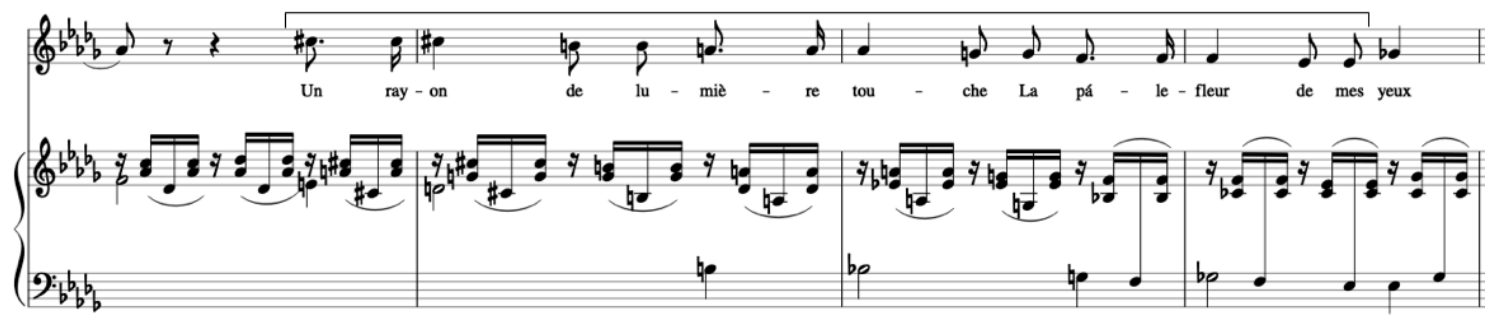

Exemplo 10: L'aube blanche, c. 11-14

Outra canção peculiar de Fauré que sugere o motivo de Lydia e que nos remete à canção de Nepomuceno é L'absent, composta em cerca de 1871, ano posterior à composição de Lydia, sobre o poema Sentiers où l'herbe se balance, de Victor Hugo, apresentado a seguir.

Sentiers où l'herbe se balance

Sentiers où l'herbe se balance,

Vallons, côteaux, bois chevelus,
Caminhos em que a grama balança,

- Caminhos em que a grama balança,

Vales, encostas e bosques cheio de folhas, 
RAMOS; PRADO

Pourquoi ce deuil et ce silence?

"Celui qui venait ne vient plus!"

Pourquoi personne à ta fenêtre?

Et pourquoi ton jardin sans fleurs?

Ô maison où donc est ton maître?

"Je ne sais pas! il est ailleurs."

Chien, veille au logis! "Pourquoi faire?

La maison est vide à présent!"

Enfant, qui pleures-tu? "Mon père!"

Femme, qui pleures-tu? "L'absent!"

Où donc est-il allé? "Dans l'ombre!"

Flots qui gémissez sur l'écueil,

D'où venez-vous? "Du bagne sombre!"

Et qu'apportez-vous? "Un cerceuil!"
Relações Intertextuais entre Canções de Nepomuceno sobre Poemas Parnasianos e Simbolistas e a Mélodie Francesa: Coração triste e Canção da ausência

$$
\begin{aligned}
& \text { Por que o luto e o silêncio? } \\
& \text { "Aquele que vinha não vem mais!" }
\end{aligned}
$$

\author{
Por que não tem ninguém na janela? \\ E por que o jardim não tem flores? \\ O casa, onde está o seu senhor? \\ "Não sei, ele está em outro lugar."
}

Cão, vigie a casa! "Por que razão?
A casa está vazia agora."
Criança, por que chora? "Meu pai!"
Mulher, por que chora? "Pelo ausente!"
Onde ele foi? "Nas sombras!"
Ondas que gemem nas rochas,
De onde vocês vêm? "Da prisão das trevas!"
E o que vocês trazem? "Um caixão!"

Cão, vigie a casa! "Por que razão?

Criança, por que chora? "Meu pai!"

"E

Segundo Johnson (2009, p. 75), Sentiers où l'herbe se balance é um dos vários fragmentos autobiográficos que Victor Hugo escreveu no início de seu exílio na Channel Islands. Foi colocado em música por Fauré dezoito anos depois, com o título L'Absent, quando o compositor deixou Paris para escapar da Comuna, como um tipo de tributo à posição histórica do grande republicano. $\mathrm{O}$ poema relata a dor da ausência sob diferentes óticas: o campo que sofre a ausência do homem, a casa que sente falta de seu dono, o cão que guarda a casa vazia, a criança que sofre a ausência do pai, a mulher que sofre a ausência de um homem que se foi para as sombras e, por último, o lamento das ondas nas rochas, vindas das prisões escuras carregando um caixão. O eu-lírico assume a voz e as angústias de diferentes personagens para revelar os próprios questionamentos e conflitos íntimos, que são intensificados por meio do afunilamento da progressão poética, que se torna mais intimista e melancólica ao longo do poema. O tom melancólico e sombrio é uma característica peculiar em L'absent (Nectoux 1991, p. 17).

O Ex. 11 mostra os primeiros compassos de L'absent, nos quais é possível ver o fragmento lídio (Fá-Sol-Lá-Si) sugerido na linha vocal dos c. 6-7. A alusão de Canção da ausência a L'absent pode ser inferida também por outras similaridades, como o movimento sincopado, o ostinato na linha do baixo, os 
ritardos na harmonia, bem como o andamento, as dinâmicas e o contorno inicial da linha vocal (embora em direção contrária). Interessante notar que L'absent não era o título original do poema, ele foi criado por Fauré, e Canção da ausência também não era o título original do poema, também foi criado por Nepomuceno.

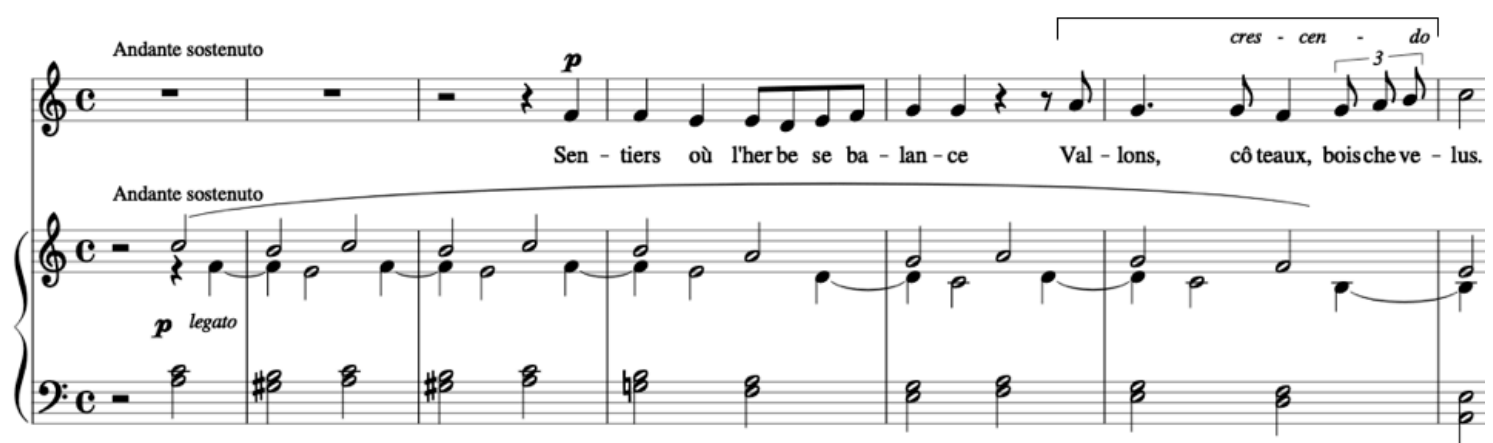

Exemplo 4: L'absent, c. 1-7

\section{Conclusão}

Partimos da hipótese que a passagem de Nepomuceno pela França causou significativo impacto na sua obra, levando-o a adotar a Mélodie francesa como modelo para as canções com textos parnasianos e simbolistas, assim como a passagem anterior pela Alemanha tivera impacto em sua música sinfônica e de câmera. A estadia de Nepomuceno na França, a composição de várias canções em francês, a aproximação a Debussy e a adoção de textos em português de características parnasianas e simbolistas são indícios fortes da influência francesa nas canções de Nepomuceno. A análise de obras paradigmáticas nesse estilo nos permitiu perceber e compreender algumas estratégias do compositor no processo de assimilação. A Mélodie francesa parece ter fornecido ao compositor um modelo de relação entre texto e música que vai muito além de apenas descrever superficialmente imagens poéticas. Poemas parnasianos e simbolistas instigaram a maestria de Nepomuceno, não apenas pela linguagem mais atual, mas também pelos desafios no estabelecimento de relações entre texto e música. A música de Fauré, simples e reservada, mas ao mesmo tempo moderna e elegante, reflexo das qualidades aristocráticas da tradição francesa, parece ter causado uma significativa influência em Nepomuceno, a qual pode ser percebida em similaridades de textura, motivos, nas estratégias de relação entre música e texto e até mesmo na escolha dos poemas, como em Coração triste e Canção da ausência. São poemas que falam de amor, mas de uma maneira elegante e contida, sem 
Relações Intertextuais entre Canções de Nepomuceno sobre Poemas Parnasianos e Simbolistas e a Mélodie Francesa: Coração triste e Canção da ausência

exageros dramáticos. Expressam sobretudo a dor da ausência da pessoa amada ou do amor não correspondido, tendo a natureza como reflexo de suas angústias e temores e imagens de um passado antigo, que revelam a saudade de um passado quando o futuro não era ameaçador ou quando ainda havia esperança de amor. E não somente as similaridades sugerem a relação entre as canções de Nepomuceno e Fauré, mas também as diferenças. Embora os poemas tenham sentidos opostos, as oposições em música acabam revelando procedimentos comuns no estabelecimento de relações entre texto e música.

A escolha pela análise das canções de Alberto Nepomuceno atende a uma demanda de estudos e informações sistematizadas sobre a obra multifacetada de Nepomuceno, a qual parece ter causado influência importante na geração posterior de compositores modernistas brasileiros. Esclarecer a ligação do compositor com as correntes modernistas francesas permite revelar uma mais efetiva participação de Nepomuceno na gênese do modernismo brasileiro como um todo, e não apenas na ênfase em temas nacionais e no canto em português, tradicionalmente difundida pela historiografia brasileira. Neste sentido, além de contribuir com reflexões sobre o conceito de intertextualidade em música, este trabalho também lança nova luz sobre a obra de Nepomuceno, trazendo à consciência o elo de ligação entre o compositor e as correntes modernistas francesas e, consequentemente, as contribuições do compositor para o desenvolvimento da música modernista brasileira.

\section{Referências}

1. Allen, G. Intertextuality: The New Critical Idiom. 2011. New York: Routledge.

2. Assis, Machado de. Phalenas. 1870. Rio de Janeiro: Paris: B.L. Garnier; E. Belhatte.

3. Azeredo, José Carlos de. 2007. Ensino de Português: fundamentos, percursos, objetos. Rio de Janeiro: Jorge Zahar Ed.

4. Barbosa, Lucas de Paula; Barrenechea, Lucia. 2005. A intertextualidade musical como fenômeno: um estudo sobre a influência da música de Chopin nas 12 Valsas de Esquina de Francisco Mignone. Em Pauta, Porto Alegre, v. 16 , n. 26, jan.jun. p. 37-72.

5. 2003. A intertextualidade musical como fenômeno. Per Musi. Belo Horizonte: Escola de Música da UFMG, v. 8, p. 125-136, jul.dez.

6. Beard, David; Gloag, Keneth. 2016. Musicology: The Key Concepts. 2. ed. New York: Routledge. 
7. Bloom, Harold. 1973. Anxiety of Influence: a Theory of Poetry. London: Oxford University Press.

8. BROCA, Brito. 2005. A vida literária no Brasil-1900. 5a. ed. Rio de Janeiro: José Olympio: Academia Brasileira de Letras.

9. BURKHOLDER, J. Peter. 1994. The Uses of Existing Music: Musical Borrowing as a Field. Notes, Second Series, v. 50, n. 3, p. 851-870, mar.

10. 2017. Borrowing. Grove Music Online. Oxford University Press. Disponível em: <http://www.oxfordmusiconline.com/subscriber/article/ grove/music/52918pg1>. Acesso em: 27 jan. 2017

11. . 2017. Intertextuality. Grove Music Online. Oxford University Press. Disponível em: <http://www.oxfordmusiconline.com/ subscriber/article/grove/ music/52853>. Acesso em: 27 jan. 2017.

12. Camargos, Marcia. 2001. Villa Kyrial: crônica da Belle Époque paulistana. São Paulo: Editora Senac.

13. Carvalhal, Tânia Franco. 2007. Literatura Comparada. São Paulo: Editora Ática.

14. Castello, José Aderaldo. 2004. A Literatura Brasileira Vol. 1: Origens e Unidade. 1a. Ed. 1a. Reimpr. São Paulo: Editora da Universidade de São Paulo.

15. Cavalcanti, Camillo. 2005. A presença da mulher na poesia na poesia parnasiana. In: Cadernos de Letras da UFF - PIBIC - GLC, n. 30-31.

16. Coelho de Souza, Rodolfo. 2006. Aspectos de modernidade na música de Nepomuceno relacionados ao projeto de tradução do Harmonielehre de Schoenberg. Em pauta, v. 17, n. 29, p. 63-81, jul./dez.

17. 2008. Influência e intertextualidade na Suíte Antiga de Alberto Nepomuceno. Música em perspectiva, v. 2, n. 2, p. 53-82, out.

18. 2009. Intertextualidade na Música Pós-Moderna. In: Sekeff, Maria de Lourdes; Zampronha, Edson. (Org.). Arte e Cultura V. São Paulo: Annablume, p. 53-74.

19. 2010. Nepomuceno e a gênese da canção de câmara brasieleira (1a parte). Música em perspectiva, v. 3. n. 1, p. 33-53, mar. 20. 2012. A influência do simbolismo nas óperas de Alberto Nepomuceno. In: VOLPE, M. A (Org.). Atualidade da Ópera (Série Simpósio Internacional de Musicologia da UFRJ). Rio de Janeiro: UFRJ - Escola de Música, Programa de Pós-graduação em Música, p. 223-231. 
Relações Intertextuais entre Canções de Nepomuceno sobre Poemas Parnasianos e Simbolistas e a Mélodie Francesa: Coração triste e Canção da ausência

21. Escudeiro, Daniel. 2015. Composição musical intertextual como alternativa para a vanguarda do século XXI. Revista Tulha. Ribeirão Preto, v. I, n. 1, p. 127142, jan.-jun.

22. Fontes, Silvana Andrade. 2019. A poesia de Hermes Fontes e o constante uso da melancolia em sua obra. In: Letras escreve - Revista de Estudos Linguísticos e Literários do Curso de Letras-UNIFAP, vol. 1, n. 2, agosto a novembro/2013. Disponível em: $<$ https://periodicos.unifap.br/index.php/letras/article/view/490>. Acesso em: 12 jun. 2019.

23. Fucci, Caroline Dunker. 2018. Os direitos autorais das obras de artes plásticas e a reprodutividade técnica: o status fático brasileiro das esculturas. Revista da EMARF, Rio de Janeiro, v. 27, n. 1, p. 33-65, nov. 2017/abr.

24. Goldberg, Luiz Guilherme. 2007. Um Garatuja entre Wotan e o Fauno: Alberto Nepomuceno e o Modernismo Musical no Brasil. Tese (Doutorado em Música) Universidade federal do Rio Grande do Sul, Porto Alegre.

25. Grout, Donald Jay; Palisca, Claude V. 1997. História da Música Ocidental. Tradução de Ana Luísa Faria. Lisboa: Gradiva.

26. Jackson, Kenneth David. 2015. Machado de Assis: A Literary Life. New Haven \& London: Yale University Press.

27. Johnson, Graham; Stokes, Richard. 2002. A French Song Companion. New York: Oxford University Press.

28. Johnson, Graham. 2009. Gabriel Fauré: The Songs and Their Poets. London \& New York: Routledge Taylor and Francis Group.

29. Klein, Michael L. 2005. Intertextuality in Western Art Music. Bloomington: Indiana University Press.

30. Klein, Michael L. Review: Reynolds, Christopher Alan. 2006. Motives for Allusion: Context and Content in Nineteenth-Century Music. Music Theory Spectrum, vol. 28, n. 1, p. 111-118, verão.

31. Korsyn, Kevin. 1991. Towards a New Poetics of Musical Influence. Music Analysis, v. 10, n. 1/2, mar./jul.

32. Kristeva, Julia. 1980. The Bound Text. In: Gora, Thomas; Jardine, Alice; Roudiez, Leon S (trad.). Desire in Language: A Semiotic Approach to Literature and Art. New York: Columbia University Press, p. 36-63.

33. Lima, Flavio F.; Pitombeira, Liduino. 2011. Fundamentos teóricos e estéticos do uso da intertextualidade como ferramenta composicional. In: Anais do XXI Congresso da ANPPOM, n. 21, Uberlândia. Música, Complexidade, Diversidade e Multiplicidade: Reflexões e Aplicações Práticas. Uberlândia: ANPPOM, p. 99-104. 
34. Martínez Pèrez, Leonardo F. 2012. Questões científicas na prática docente: ideologia, autonomia e formação de professores. São Paulo: Ed. UNESP.

35. Nectoux, Jean-Michel. 1991. Gabriel Fauré: A Musical Life. New York: Cambrigde University Press.

36. Noske, Frits. 1970. French Song: from Berlioz to Duparc. Tradução de Rita Benton. New York: Dover Publications.

37. Pignatari, Dante. 2009. Canto da língua: Alberto Nepomuceno e a invenção da canção brasileira. Tese (Doutorado em Letras). Faculdade de Filosofia, Letras e Ciências Humanas, Universidade de São Paulo, São Paulo.

38. Pignatari, Dante (ed.). 2013. Alberto Nepomuceno: Canções para voz e piano. São Paulo: Editora da Universidade de São Paulo.

39. Pinto, Marta Pacheco. 2019. A lira chinesa em trânsito: de Machado de Assis a António Feijó. In: Scientia Traductionis, n.14, 2013. Disponível em: < http://dx.doi.org/10.5007/1980-4237.2013n14p93>. Acesso em: 9 de jun. 2019.

40. Reynolds, Christopher A. 2003. Motives for Allusion: Context and Content in Nineteenth-Century Music. Massachusetts: Harvad University Press,

41. STEIN, Deborah; SPILLMAN, Robert. 1996. Poetry in to Song: Performance and Analysis of Lieder. New York: Oxford University Press.

42. Straus, Joseph N. 2013. Introdução à Teoria Pós-tonal. Salvador-São Paulo: Editora UNESP - EDUFBA.

43. . 1990. Remaking the Past. Cambridge: Harvard University Press.

44 . 1991. The "Anxiety of Influence" in Twentieth-Century Music. The Journal of Musicology, v. 9, n. 4, p. 430-447, outono.

45. Vermes, Viviana Monica. 1996. Alberto Nepomuceno e a Criação de uma Música Brasileira: evidências em sua música para piano. Dissertação (Mestrado em Artes) - Instituto de Artes, UNESP, São Paulo.

46. Vidal, João V. 2011. Nepomuceno e Max Bruch: análise de uma (recémdescoberta) conexão. Revista Brasileira de Música - Programa de Pósgraduação em Música - Escola de Música da UFRJ, v. 24, n. 1, p. 129-153, jan./jun.

47. Walter, Judith. 2019. Le Livre de Jade. Paris: Alphonse Lemerke, 1867. Disponível em: <https://archive.org/details/lelivredejade00gaut/page/n7>. Acesso em: 20 jun. 2019. 